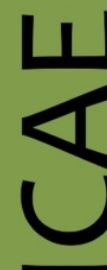

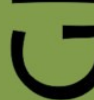

ex Instituto Archaeologico Universitatis de Rolando Eötvös nominatae

O

$\overrightarrow{0}$

山

$\leftarrow$

I

$\cup$

ه

$\leftarrow$

u

Ш

Z

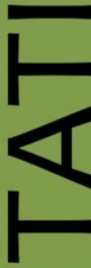

œ

ш

n

n

$\varnothing$
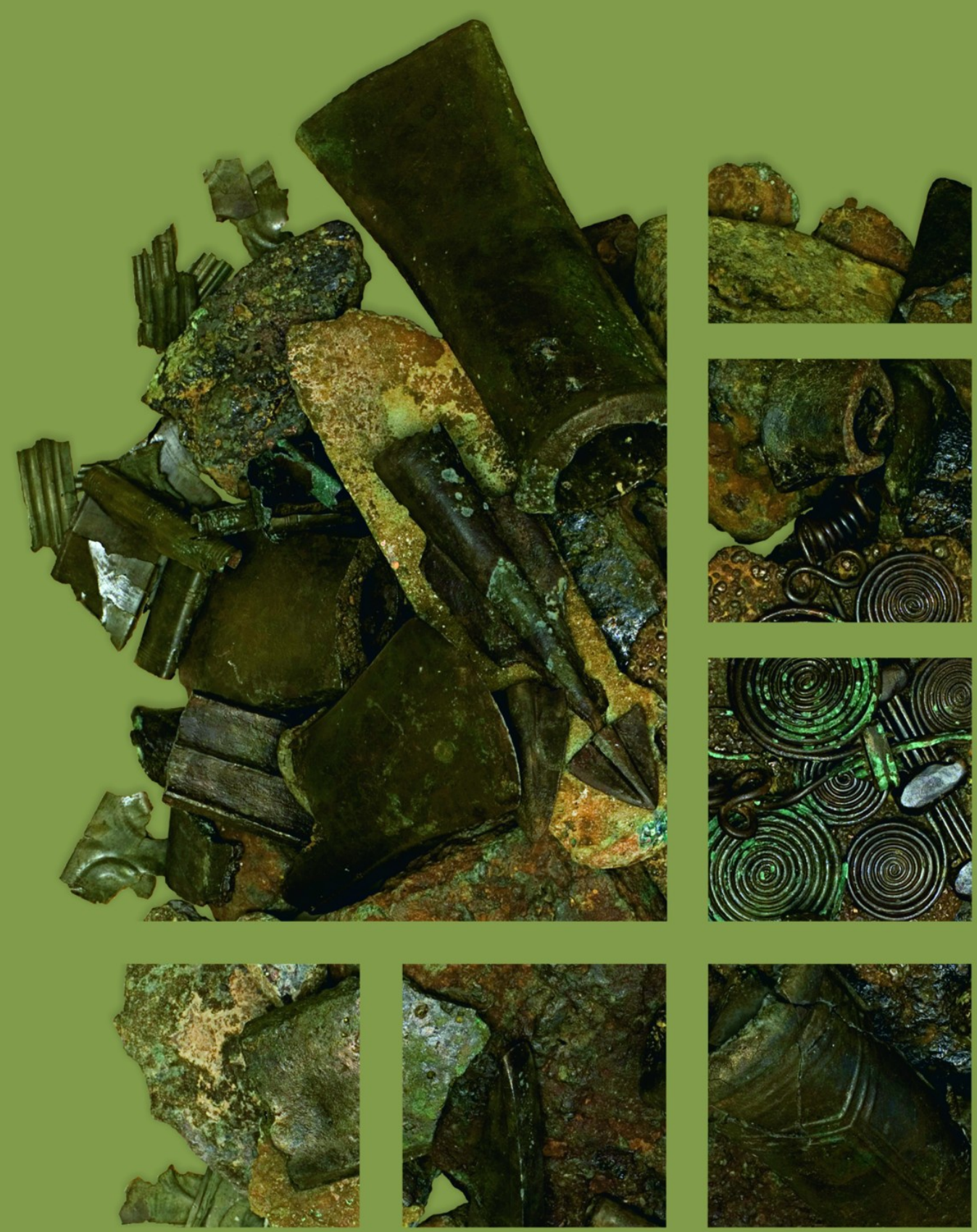


\section{Dissertationes Archaeologicae ex Instituto Archaeologico}

Universitatis de Rolando Eötvös nominatae Ser. 3. No. 2.

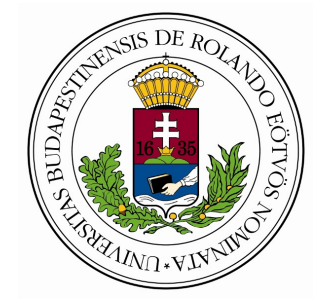

Budapest 2014 
Dissertationes Archaeologicae ex Instituto Archaeologico Universitatis de Rolando Eötvös nominatae

Ser. 3. No. 2.

Editor-in-chief:

DÁvid BARTus

Editorial board:

LÁsZló BARTOSIEWICZ

LÁSZLÓ BORHY

IsTVÁN FELD

GÁBOR KALLA

PÁL RACZKY

MiKLÓs SzABÓ

TIVADAR VIDA

Technical editors:

DÁvid BARTus

GÁBOR VÁCZI

ANDRÁs BÖDŐCS

DÁNIEL SZABÓ

Proofreading:

SZILVIA SzÖLLősI

Available online at http://dissarch.elte.hu Contact: dissarch@btk.elte.hu

$$
\begin{aligned}
& \text { PUBLIC } \\
& \text { KNOWLEDGE } \\
& \text { PROJECT }
\end{aligned}
$$

(c) Eötvös Loránd University, Institute of Archaeological Sciences

Budapest 2014 


\section{Contents}

\section{SElected PAPERS OF THE XI. Hungarian CONFERENCE on Classical Studies}

Ferenc BARNA

Venus mit Waffen. Die Darstellungen und die Rolle der Göttin in der Münzpropaganda

der Zeit der Soldatenkaiser (235-284 n. Chr.)

Dénes GABLER

A belsó vámok szerepe a rajnai és a dunai provinciák importált kerámiaspektrumában

Lajos MATHÉDESZ

Római bélyeges téglák a komáromi Duna Menti Múzeum gyújteményében

Katalin OtTOMÁNYI

Újabb római vicusok Aquincum territoriumán

Eszter SÜVEGH

Hellenistic grotesque terracotta figurines. Problems of iconographical interpretation

András SzABó

Some notes on the rings with sacred inscriptions from Pannonia

István VIDA

The coinage of Flavia Maxima Helena

\section{Articles}

Gábor TARBAY

Late Bronze Age depot from the foothills of the Pilis Mountains

Csilla SÁRó

Roman brooches from Paks-Gyapa - Rosti-puszta

András BöDőcs - Gábor KovÁcs - Krisztián ANDERKó

The impact of the roman agriculture on the territory of Savaria

Lajos JuHÁsz

Two new Roman bronzes with Suebian nodus from Brigetio

\section{FIELD REPORTS}

Zsolt MESTER - Norbert FARAGó - Attila KirÁLy

The first in situ Old Stone Age assemblage from the Rába Valley, Northwestern Hungary

Pál RACZky - Alexandra ANDERs - Norbert FARAgó - Gábor MÁRKus

Short report on the 2014 excavations at Polgár-Csőszhalom 
Preliminary Report on the first season of fieldwork in Berettyóúffalu-Szilhalom

Márton SzILÁgyi - András FüZESI - Attila VIRÁG - Mihály GASPARIK

A Palaeolithic mammoth bone deposit and a Late Copper Age Baden settlement and enclosure

Preliminary report on the rescue excavation at Szurdokpüspöki - Hosszú-dúlö II-III. (M21 site No. 6-7)

Kristóf FüLÖP - Gábor VÁcZI

Preliminary report on the excavation of a new Late Bronze Age cemetery

from fobbágyi (North Hungary)

Lőrinc TimÁr - Zoltán CzAJLik - András BöDőcs - Sándor PuszTA

Geophysical prospection on the Pâture du Couvent (Bibracte, France). The campaign of 2014

Dávid BARtus - László Borhy - Gabriella Delbó - Emese SzÁmadó

Short report on the excavations in the civil town of Brigetio (Szőny-Vásártér) in 2014

Dávid BARTus - László BorHy - Emese SzÁMADó

A new Roman bath in the canabae of Brigetio

Short report on the excavations at the site Szőny-Dunapart in 2014

Dávid BARTus - László Borhy - Zoltán CzAjlik - Balázs Holl -

Sándor PuszTA - László RuPNiK

Topographical research in the canabae of Brigetio in 2014

Zoltán CZAJLIK - Sándor BERECKI - László RUPNIK

Aerial Geoarchaeological Survey in the Valleys of the Mureș and Arieș Rivers (2009-2013)

Maxim MoRDovin

Short report on the excavations in 2014 of the Department of Hungarian Medieval

and Early Modern Archaeology (Eötvös Loránd University, Budapest)

Excavations at Castles Čabrad' and Drégely, and at the Pauline Friary at Sáska

\section{Thesis Abstracts}

Piroska Csengeri

Late groups of the Alföld Linear Pottery culture in north-eastern Hungary

New results of the research in Borsod-Abaúj-Zemplén County

Ádám Bíró

Weapons in the 10-11th century Carpathian Basin

Studies in weapon technology and methodology - rigid bow applications and southern import

swords in the archaeological material

Márta DARÓcZI-SzABó

Animal remains from the mid 12th-13th century (Árpád Period) village of Kána, Hungary

Károly BELÉNYESY

A 15th-16th century cannon foundry workshop in Buda

Craftsmen and technology of cannon moulding and the transformation of military technology

from the Renaissance to the Post Medieval Period 
István RINGER

Manorial and urban manufactories in the 17th century in Sárospatak

\section{BIBLIOGRAPHY}

László BORHY

565

Bibliography of the excavations in Brigetio (1992-2014) 


\title{
Preliminary report on the first season of fieldwork in Berettyóújfalu-Szilhalom
}

\author{
DANiEl NeUmanN \\ Romano-Germanic Commission \\ of the German Archaeological Institute \\ daniel.neumann@dainst.de
}

\author{
ROMAN SCHOLZ \\ Romano-Germanic Commission \\ of the German Archaeological Institute \\ roman.scholz@dainst.de
}

\author{
ZsuzSANNA SikLÓsI \\ Institute of Archaeological Sciences \\ Eötvös Loránd University \\ siklosi.zsuzsanna@btk.elte.hu \\ MÁrton SZILÁgyi \\ Institute of Archaeological Sciences \\ Eötvös Loránd University \\ szilagyi.marton84@gmail.com
}

\begin{abstract}
This study aims to present the first results of fieldwork conducted by the teams of the Römisch-Germanische Kommission (Frankfurt am Main) and the Institute of Archaeological Sciences of Eötvös Loránd University (Budapest) in the scope of a joint project. The investigated tell site, Berettyóúfalu-Szilhalom is well known by prehistoric archaeology due to earlier excavations. The main goals of the project were to gain a better understanding of Late Neolithic tell formation processes, to investigate the relations of a tell and its adjacent horizontal settlement and to get a more detailed picture on the Late Neolithic-Early Copper Age transition. Therefore we re-opened the refilled trench of the excavation carried out in 1976, collected bone, soil and micromorphological samples for further examinations, performed geomagnetic prospections, made drillings and field surveys.
\end{abstract}

\section{Introduction}

A joint project was established between the Romano-Germanic Commission of the German Archaeological Institute (RGK) and the Institute of Archaeological Sciences of the Eötvös Loránd University (ELTE) in 2013 which aims to research the social transformations in the Berettyó region during the Neolithic and Copper Age.

Between the Late Neolithic and Early Copper Age - around 4600-4500 cal BC - considerable transformations in the archaeological record became visible throughout almost the whole Carpathian Basin. It is expressed by a major change in the material culture and the organisation of settlements. Several studies have focused on the transformation of settlement patterns, and it has been widely accepted that the Late Neolithic predominantly tell-based settlement system had been replaced by a network of dispersed smaller settlements in the beginning of the Early Copper Age. ${ }^{1}$ In the last few decades due to problem-oriented research projects and salvage excavations our knowledge about Late Neolithic settlement system has been significantly widened. It seems clear that the tell itself was usually only one part of the

1 Sherratt 1983; Kalicz - Raczky 1987a; Kalicz 1995; Raczky 1995; Parkinson 2006; Parkinson - Gyucha 2007; PARKinson ET AL. 2010; Duffy ET AL. 2013; RACZKy Et AL. 2014. 
whole settlement and a large flat settlement was adjacent to it (e. g. Berettyóújfalu-Herpály, ${ }^{2}$ Szegvár-Tűzköves, ${ }^{3} \quad$ Szarvas-Kovácshalom, Békés-Povád, ${ }^{4}$ Polgár-Csőszhalom, ${ }^{5}$ PolgárBosnyákdomb, ${ }^{6}$ Hajdúböszörmény-Pródi-halom, ${ }^{7}$ Szeghalom-Kovácshalom ${ }^{8}$ ). Similar results were drawn from research in Southeast Europe. ${ }^{9}$ Simultaneously, as a result of long-term changes, with the continuity of numerous elements of the burial rites beside the single settlement burials, small grave groups within settlements and formal cemeteries spatially separated from settlements appeared at around $4300 \mathrm{cal} \mathrm{BC.} .^{10}$

As explanations for the decline of the tell-centered settlement system and the transformation different models were built. Their majority tried to generalise the picture drawn from single sites to a microregion or a wider region. At the same time, primarily due to the problem-oriented research projects of the last two decades and Bayesian modelling of radiocarbon dates local differences can be studied more easily. For instance, owing to the more and more precise absolute chronology we can see that the cessation of Late Neolithic tells on the Great Hungarian Plain did not take place contemporaneously. Therefore a multi-perspective reappraisal and assembling of data on a local scale seems crucial.

On the other hand, we can observe local variability concerning either material culture or settlement system. For this reason we think that results of regional surveys from the Körös region or from the Polgár region cannot be generalised to the whole Great Hungarian Plain. Our study focused on a single site and its immediate vicinity within a small region that has a long - especially Neolithic - research history. However, modern trends of interdisciplinary and multidisciplinary archaeology avoided to research in this area, even if according to our present knowledge it is of a great importance in the understanding of the Late NeolithicEarly Copper Age transition. Local differences between settlements can be clearly seen in a smaller microregion or region, therefore we think that examining local variability is essential in the understanding of prehistoric societies.

Our interest turned to one of the well-known tell settlements, Berettyóújfalu-Szilhalom, as a site that can provide a good opportunity to investigate the above mentioned problems from a different, local-scale point of view. The key aims of the first field season at BerettyóúffaluSzilhalom and its vicinity, which was performed in the autumn of 2013, were performing geophysical prospection, checking the stratigraphic sequence of the tell and collecting samples to establish a framework of $14 \mathrm{C}$-dates.

\section{Berettyóújfalu-Szilhalom and its vicinity}

Nowadays the area is intensively used for agriculture but before the draining of the 19th century the Berettyó river system was a very swampy biotope. ${ }^{11}$ The area around the modern town of Berettyóújfalu in Hajdú Bihar County has a long tradition of prehistoric research. ${ }^{12}$

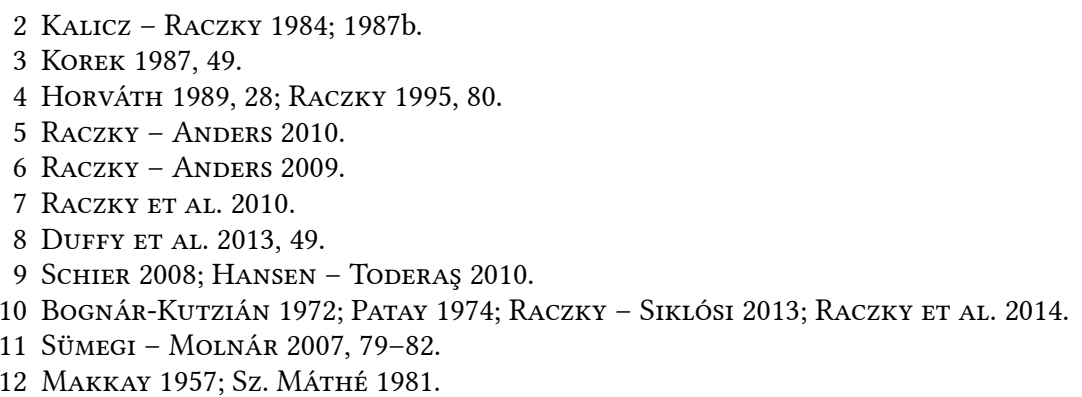


Beside the eponymous site of Late Neolithic Herpály culture ${ }^{13}$ a regular network of Late Neolithic tells is observable. ${ }^{14}$

The Szilhalom project itself within the scope of a German-Hungarian cooperation was preceded by systematic field surveys in the vicinity of Berettyóúffalu by the Hungarian team. The area of the known Late Neolithic tells (Szentpéterszeg-Kovadomb, Berettyóújfalu-Herpály, Berettyóújfalu-Szilhalom, Berettyóújfalu-Berta-domb) was surveyed, thereby we found an adjacent horizontal settlement in every case. All of these tells - regarding to earlier excavations or our surveys - might have been inhabited at the beginning of the Copper Age (Fig. 1-2). ${ }^{15}$

The tell-like settlement of Berettyóújfalu-Szilhalom lies on a natural loess plateau overlooking a paleomeander (nowadays Szilér channel) (Fig. 3). There is a difference of height of about 7 meters between the top of the mound and the channel. In the centre of the tell an $8 \times 5 \mathrm{~m}$ trench was opened in 1976, which was broadened to the North with 3 meters in 1979 within the frame of a research project primarily devoted to the study of Bronze Age layers. Solely the Bronze Age layers have been published from this excavation, ${ }^{16}$ whilst the archaeological finds of the Neolithic and Copper Age layers still remained unpublished. ${ }^{17}$ This well-bounded area provides ideal conditions for the examination of diachronic development of tell/tell-like settlements and flat settlements in its immediate vicinity.

\section{Field Survey}

The Hungarian team started systematic intensive field survey in the vicinity of Berettyóúffalu in spring 2013 and continued in autumn $2013 .{ }^{18}$ We collected finds in $50 \times 50 \mathrm{~m} \mathrm{~N}-\mathrm{S}$ oriented grids on 50 hectares overall. The finds were located with handheld GPS. The main goal of the field survey was a rough estimation of the extension of sites and separate archaeological periods within them. This survey revealed traces of prehistoric habitation to the South of the tell as far as the paleomeander (Berettyóúffalu-Réti föld) and on the elevations to the West and East (Berettyóúffalu-Kis-Kenderes-kert). In the selection of this area for intensive fieldwork, the easy definition of spatial boundaries was an important criterion. The human presence at the sites Berettyóújfalu-Szilhalom, -Réti-föld and -Kis-kenderes-kert was - according to field survey and the excavation carried out in 1976 and $1979^{19}$ - continuous from the Middle Neolithic to the Early Copper Age, then the area was re-settled in the Middle Bronze Age (Fig. 4-8). Later periods were present in smaller number.

We refined this method of collection during the 2013 autumn season, when we collected every archaeological find in $20 \times 20$ meters grid sections, in 2.8 hectares overall. Although, the archaeological and geoinformatical analysis of this great amount of finds is still in process, we think that comparing the quantity of finds from different archaeological periods with the results of the geomagnetic prospection can help us to approximately date the anomalies seen on the magnetometry.

\footnotetext{
13 Kalicz - Raczky 1984; 1987b; Kalicz et AL. 2011.

14 KALICZ 1995.

15 On the problem of Prototiszapolgár expression see RACZKy ET AL. 2014, 331-332.

16 Sz. MÁTHÉ 1988.

17 Besides mentioned in short reports (Sz. MÁTHÉ 1980; 1981, 19).

18 OTKA 101062.

19 Sz. MáthÉ 1980.
} 


\section{Topographical and Geomagnetic Survey}

The tell and its vicinity (in total 4.5 hectares) were, on the one hand, topographically surveyed using a Differential-GPS and, on the other hand, geophysically prospected by using a SENSYS five sensor magnetometer. The assembled data was processed by using the software MAGNETO-ARCH, Surfer 9 and AutoCAD 2010. Besides locating the excavation trench of the 1976 the magnetogram uncovered an enormous density of magnetic anomalies (Fig. 9). Apart from some modern intrusions almost all detected features seem to be archaeological remains, but certainly their dating has to be proven by further research. For a short overview at this stage of examination the features that were revealed by the geomagnetic survey were roughly grouped (Fig. 10).

The first group covers linear structures of different size. As the magnetogram suggests there are two different ditches surrounding the tell site. These ditches were probably attached to a larger system that was uncovered on the neighbouring slopes in eastern and western direction. At this stage it seems that these ditches formed a large enclosure system, which may be - according to the field survey - also embracing the possible areas of a flat settlement. But certainly the exact layout and dating has to be specified in the future. Besides the larger ditches surrounding the tell site a line of smaller anomalies was traced which formed presumably a palisade delimiting the site from the channel to the North.

The second group of anomalies contains the features on the tell which mainly derive from burnt structures. As by geomagnetics the topmost anomalies are detected in the first place and because it is known from Szilhalom that Bronze Age layers revealed burnt houses these features are probably attached to this period. Because of its multiphase character chronological or functional distinction of magnetic anomalies are impossible on a tell.

The third group comprehends two large rectangular houses on the eastern slopes which were clearly burnt and an area of larger quantity of smaller rectangular features which are presumably mainly the remains of houses as well.

The last group consists of small features which are typical for prehistoric flat settlements and which may be pits, ovens and other smaller intrusions.

Similar systems of tell, enclosure and adjacent horizontal settlement can be seen on geomagnetic prospections of both Late Neolithic (i.e. Polgár-Csőszhalom, ${ }^{20}$ Hajdúböszörmény-Pródi halom, ${ }^{21}$ Uivar $^{22}$ ) and both Middle Bronze Age ${ }^{23}$ sites. Some smaller Early Copper Age settlements were also surrounded by a circular ditch (i.e. Vésztő- and Körösladány-Bikeri ${ }^{24}$, Battonya-Vertán-major ${ }^{25}$ ). Thus solely the excavation of some exemplary features will enable a dating and a discussion of diachronic development of this site. As a first step we took drilling samples from the ditch in the autumn season of 2014.

\section{Reopening the excavation trench}

After locating the trench on the tell by geophysics it was reopened by an excavator. After the removal of most of the backfilled earth we cleaned the bottom and the eastern profile of

\footnotetext{
20 RACZKY ET AL. 2011.

21 RACZKY ET AL. 2010, figs 9-10.

22 SCHIER 2008, fig. 2.

23 FISCHL - KIENLIN 2013, figs 4A and 5.

24 PARKInSON ET AL. 2010, figs 7. and 10

25 Goldman - SzÉnÁszKy 2012, fig. 2.
} 
the old trench using hand-tools. With this reappraisal the stratigraphic sequence that was recorded during the excavation of the 1976 could be proven. ${ }^{26}$

According to this small insight the first sequence on the tell is assigned to the Middle $\mathrm{Ne}$ olithic (Esztár group of the Alföld Linear Pottery) by a large pit. Its northern part had been excavated in 1976, however, the southern part remained intact (Fig. 11-13).

This feature was superimposed by a $60 \mathrm{~cm}$ thick layer upon which a Late Neolithic (Herpály) house was built. This layer seemed to be homogeneous, we could detect no stratification, its colour was dark grey, with some finds. It is presumably an artificial filling (Fig. 11-12). According to the thin layers inside of the Late Neolithic house it seems that several renewal of the floor may have been preserved.

Above the Late Neolithic house another approximately $70 \mathrm{~cm}$ thick homogeneous layer could be observed which seemed to be artificial as well. This assumption can only be supported by further examinations. Above this layer only a recent disturbance could be detected probably due to the fact that the trench remained unfilled for a long time after the excavations carried out in the 1970's (Fig. 11-12).

In order to find the Copper Age layer we broadened our trench to the North in the line of the eastern profile $1 \mathrm{~m}$ long and $70 \mathrm{~cm}$ wide. We could identify the debris of the Early Copper Age house excavated in 1976 under a filling and three layers of - presumably Bronze Age houses (Fig. 11).

Apart from collecting samples for dating the layers, the profile were examined geoarchaeologically, ${ }^{27}$ by applying geochemical analyses using a portable $\mathrm{XRF},{ }^{28}$ micromorphology and microbiological soil analyses. ${ }^{29}$

The results of the particular analyses together with the archaeological dating will hopefully shed new light on the tell formation process at this site. The first preliminary results of the analyses show correlations concerning the quantity of human impact, of which the layer between the end of the Middle Neolithic and the Late Neolithic house has the lowest intensity. Hopefully the micromorphological samples may reveal if there has been past surfaces preserved or if this is the result of deliberate levelling.

The first traces of human habitation at the site can be dated to the younger phase of the Middle Neolithic. The pit and probably an associated settlement were built upon a little elevation which rose only some meters from above a presumably wet area (Fig. 14).

The old trench had reached the virgin soil, and the majority of the archaeological features were excavated in 1976. We re-excavated them and with a few earlier not unearthed postholes they are presumably parts of two timber-framed houses with parallels found in Berettyóujfalu-Herpály ${ }^{30}$ and Polgár-Csőszhalom ${ }^{31}$ (Fig. 15). Since the majority of these features were unearthed earlier, no finds and no stratigraphic observations can support our assumption, but only structural similarities. 


\section{Material Culture}

The Middle Neolithic pit contained many characteristic sherds of the Esztár group. Pottery with incised decoration - bowls and thick pots decorated with incised lines - occurred in a relatively low number, however, the characteristic decoration of the Esztár group (globular vessels with curvilinear motifs painted in black, purple-red slip applied before firing, flat bowls with wide red painted lines) could be observed several times on well elaborated fine ware pieces. Besides them we found thick-walled big-sized coarse ware and a small conical cup decorated with flat knobs (Fig. 16). Parallels can be found at several nearby sites $^{32}$ (furthermore see: Berettyószentmárton-Morotva, ${ }^{33}$ Biharkeresztes-Kis Szárcsás dűlö ${ }^{34}$ ).

Only a few characteristic sherds came to light from the Late Neolithic Herpály layer (Fig 17). ${ }^{35}$ A wide scale of finds from this period are known from the eponymous site of Herpály tell, which is found $3 \mathrm{kms}$ to the Northeast. ${ }^{36}$

Although our control excavation reached the Early Copper Age layer on a very small area, we found numerous characteristic pieces of Tiszapolgár pottery among the debris of a house. Prominent pieces are a hollow-pedestalled semispheric bowl with round perforations on the pedestal, and pointed knobs on the upper part, and a side fragment of a vessel with horizontally pierced lugs (Fig. 18). According to the material of the Layer 5 of the Herpály tell, N. Kalicz and P. Raczky described the pottery characterised by pointed knobs, perforated pedestals and impressed decoration as the so-called Prototiszapolgár phase of the Late Neolithic Herpály Culture which was a continuous transformation into the Early Copper Age. They identified this material with the Tiszapolgár A described by I. Bognár-Kutzián. They assumed that the majority of Tiszapolgár A assemblages collected by Bognár-Kutzián stem from the top of Herpály tells. ${ }^{37}$ The Early Copper Age material from Szilhalom can be classified stylistically rather to the Tiszapolgár Culture. ${ }^{38}$

\section{Radiocarbon Dating and Bayesian Modelling}

From the profile of the trench a total of 14 animal bone samples were taken for AMS dating (Fig. 19) in Klaus-Tschira-Labor, Curt-Engelhorn-Zentrum Archaeometrie (Mannheim). The radiocarbon data have been calibrated with the OxCal 4.2.4 ${ }^{39}$ software and the IntCal13 calibration curve. ${ }^{40}$ Bayesian analyses were applied to derive the posterior density estimates for the beginning and end of each period on the site. ${ }^{41}$ Calibrated radiocarbon dates are discussed using the one sigma values.

Several different models were prepared in accordance with our stratigraphic observations. The analyses revealed that three radiocarbon measurements were outliers therefore they were finally omitted from the model. These outliers were the samples from the pit F002/S002 (MAMS20496 and MAMS-20 503) whose calibrated date fall into the period of Middle Neolithic but the pit cut not only the Middle Neolithic layers but the lower floor of the Late Neolithic house as

32 KALICZ - MAKKAY 1977, 52-56.

33 Sz. Máthé 1978.

34 Hajdú - NAgY 2000.

35 Pottery from the older excavation see Sz. MÁthé 1981, 16, fig. 6-8.

36 KALICZ - RACZKY 1984; 1987b.

37 Bognár-Kutzián 1972, 183-194, Pl. 6.1-10, Pl. 15.1-17, Pl. 70.1-9; Kalicz - RaczKy 1984, 115, 132-133, fig. 40.

38 Pottery from the older excavation see Sz. MÁthé 1981, 21, fig. 9-10.

39 BRONK RAMSEY 2013.

40 Reimer ET AL. 2013.

41 Buck et AL. 1991; Bronk Ramsey 2009. 
well. The filling of this pit was extremely poor in finds therefore it was difficult even to collect samples for radiocarbon dating. In this case it is very probable that the samples were mixed into the fill of the pit from the earlier layers. The third outlier was the sample MAMS-20 504 deriving from the debris of the Early Copper Age house F011/S040. Because of the temporal proximity of the Late Neolithic and Early Copper Age layers, only the Bayesian modelling could reveal that the sample probably derived from the Late Neolithic.

Bayesian modelling based on the eleven reliable AMS measurements (Fig. 20) estimate the start boundary after that the use of the site could begin 5310 (68.2\%) 5210 cal BC (Fig. 21.1). The four samples deriving from the different layers of the Middle Neolithic pit indicate a use-life of the pit of 0 (68.2\%) 150 years (Fig. 21.2), and the end boundary before this part of the Middle Neolithic settlement could be abandoned is 5220 (68.2\%) 5055 cal BC (Fig. 21.3).

Conventional radiocarbon measurements were taken on the samples deriving from the excavation in 1976..$^{42}$ These re-calibrated dates are 5380 (68.2\%) $5220 \mathrm{cal} \mathrm{BC}$ and 5470 (68.2\%) 5210 cal BC. Although, the exact archaeological context of these old samples are unknown but the single excavated Middle Neolithic pit is identical with the one that we revealed. Taking into consideration the bigger standard deviation of conventional radiocarbon measurements and that these measurements were taken on charcoal samples, these older dates roughly coincide with our new results.

F. Horváth and E. Hertelendi dated the appearance of Esztár finds on the ALPC Phase 2 between 5300 and $5200 \mathrm{cal}$ BC based on the conventional measurements of Szilhalom among others, ${ }^{43}$ but F. Horváth and F. Draşovean have recently considered an even earlier dating. ${ }^{44}$ The new data from Szilhalom cannot confirm this earlier dating of the Esztár group.

Samples deriving from the thick fill following the Middle Neolithic pit chronologically are closer to the dates of the Late Neolithic house. Thereby the AMS samples prove that the layer preceding the Late Neolithic house also dates to the Late Neolithic. The interval between the end of the Middle Neolithic settlement and the beginning of the Late Neolithic settlement can be estimated 135 (68.2\%) 420 years (Fig. 21.4). The beginning of the Late Neolithic settlement could be dated after 4915 (68.2\%) 4710 cal BC (Fig. 21.5) and its abandonment can be estimated before 4515 (68.2\%) 4450 cal BC (Fig. 22.1), indicating a use-life of 45 (68.2\%) 160 years for the whole Late Neolithic period on the site (Fig. 22.2). All these suggest that the thick fillings between the layers of houses could be the results of intentional levelling works. Results of the ongoing micromorphological analysis will help to solve this problem.

One conventional measurement had been earlier taken on a Late Neolithic sample ${ }^{45}$ - the precise archaeological context of the sample is unkown - whose re-calibrated date (4540 $(68.2 \%)$ $4490 \mathrm{cal}$ BC) harmonizes well with the end of the estimated dating of Late Neolithic period based on AMS dates.

Following the end of the Late Neolithic, an interval of $0(68.2 \%) 50$ years can be estimated (Fig. 22.3) which is represented by a thick filling. The beginning of the Early Copper Age can be estimated after 4475 (68.2\%) 4400 cal BC (Fig. 22.4), and the site could be abandoned before 4460 (68.2\%) 4335 cal BC (Fig. 22.5).

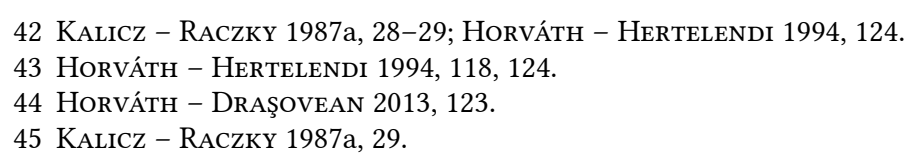


E. Hertelendi and his colleagues dated the Late Neolthic Tisza-Herpály-Csőszhalom complex between 4860 (68.2\%) 4490 cal BC and the Prototiszapolgár between 4570 (68.2\%) 4270 cal BC based on conventional measurements taken from charcoal samples. ${ }^{46}$ The majority of Late Neolithic tells on the Great Hungarian Plain can be dated even now solely by these conventional measurements except for some new AMS measurements discussed in detail below. The end of the Late Neolithic period on Szilhalom perfectly coincides with the end of Polgár-Csőszhalom tell (end boundary: 4516 (68.2\%) 4455 cal BC) where the oldest Early Copper Age find material (formerly called Prototiszapolgár) was not found. ${ }^{47}$ On the contrary, the radiocarbon dates (4612 (68.2\%) $4503 \mathrm{cal} \mathrm{BC}$ and $4581(68.2 \%) 4461 \mathrm{cal} \mathrm{BC)}$ of the youngest, "Prototiszapolgár" layer of Polgár-Bosnyákdomb are contemporary or even older than the abandonment of Csőszhalom. ${ }^{48}$ Layer 5 of Berettyóújfalu-Herpály can be dated only by conventional measurements (after re-calibration and Bayesian modelling: 4596 (68.2\%) $4328 \mathrm{cal}$ BC). ${ }^{49}$ These old measurements yield such a wide time-interval that is methodologically hardly comparable with the results of AMS dates. The beginning of Vésztö-Bikeri Early Copper Age settlement can be dated after the end of Szilhalom Early Copper Age layer, only Körösladány-Bikeri ${ }^{50}$ might have started to use before the Early Copper Age settlement on Szilhalom was abandoned. The Early Copper Age radiocarbon data of Vésztő-Mágor tell (4345 $(68.2 \%) 4081 \mathrm{cal}$ BC) suggest rather re-settling on the tell instead of a continuos use from the Late Neolithic. $^{51}$

\section{Conclusion}

The control excavation in Berettyóúffalu-Szilhalom and the samples that could be taken from the eastern profile for further examination provide us an opportunity to evaluate the material of the old excavation according to modern high scientific standards. On the one hand, the radiocarbon dates published here are the first AMS dates from verified archaeological context which is an important step forward to connect this area to the better investigated neighbouring areas. On the other hand, the soil and micromorphological examinations that are still in process could contribute significantly to our understanding of the tell formation process, and magnetometry could add important informations on the relationship of the tell and the adjacent areas.

As an interesting result we must draw attention to the time gap between the Middle Neoltihic and the Late Neolithic features, the radiocarbon dates suggest at least more than a hundred (rather even more) years of no occupation. On this basis we can state that the beginnings of the tell formation process in Szilhalom cannot be dated to the end of the Middle Neolithic.

As it became clear in the case of Polgár-Csőszhalom and -Bosnyákdomb even neighbouring and contemporaneous sites cannot be described with the same model. We can see a similar situation between Berettyóúffalu-Herpály and -Szilhalom sites that are separated only by 3 kilometers. Massive thick layers of burnt Late Neolithic houses that could be observed at Herpály are missing at Szilhalom, whilst at the latter site - as it seems for now - the settlement layers characterised by Late Neolithic Herpály and Early Copper Age Tiszapolgár ceramic

46 HeRTELENDI ET AL. 1995, 241-242.

47 RACZKY ET AL. 2014, 332; RACZKY ET AL. in press.

48 RACZKY - ANDERS 2009, 16-17.

49 YERKES ET AL 2009, 1079.

50 YeRKes et AL. 2009, 1084.

51 YERKES ET AL. 2009, 1085-1087. 
styles suggests that the use of the site had been continuous. Although the use of numerous Late Neoltihic tells came to an end at latest in the period earlier described as Prototiszapolgár (i.e. Hódmezővásárhely-Gorzsa ${ }^{52}$ ), several settlements were inhabited constantly until the beginning of the Copper Age (i.e. Uivar ${ }^{53}$ ) or even any longer (i.e. Crna Bara ${ }^{54}$, where Tiszapolgár and Bodrogkeresztúr layers covered the Tisza and Vinča layers). Accordingly it is unambiguous that the socio-cultural changes on the Great Hungarian Plain cannot be described and circumscribed within one single model, they might not been fully general and contemporaneous. We cannot generalize the observations of a microregion or a region to the whole Plain but we can reckon with a more mosaic socio-cultural picture than it was assumed earlier. On the other hand, the complex changes at the Late Neolithic-Early Copper Age transition took place in a longer time period, and terminated around $4300 \mathrm{cal}$ BC when besides the new settlement system the formal cemeteries appeared and metallurgy reached a higher level. ${ }^{55}$

\section{Acknowledgements}

Besides the authors the participants of the field season 2013 were: Nadine Baumann (RGK) and Swetlana Peters (Goethe University), students of the Eötvös Loránd University (Zoltán Berente, Ádám Békési, Csenge Márkus). The animal bones were analyzed by P. Csippán (ELTE). We are grateful for their assistance. The field survey of the ELTE team was funded by the Hungarian Scientific Research Fund (OTKA 101062 "Chronological and spatial relations of Early and Middle Copper Age settlements, cemeteries and metal finds on the Great Hungarian Plain").

\section{References}

BognáR-Kutzián, I. 1972: The Early Copper Age Tiszapolgár Culture in the Carpathian Basin. Archaeologia Hungarica 48. Budapest.

Bronk RAmsey, C. 2009: Bayesian analysis of radiocarbon dates. Radiocarbon 51/1, 337-360.

Buck, C. E. - Kenworthy, J. - Litton, C. D. - Sмith, A. M. F. 1991: Combining archaeological and radiocarbon information: a Bayesian approach to calibration. Antiquity 65, 808-821.

Duffy, P. R. - Parkinson, W. - Gyucha, A. - Yerkes, R. W. 2013: Coming Together, Falling Apart. A Multiscalar Approach to Prehistoric Aggregation and Interaction on the Great Hungarian Plain. In: Birch, J. (ed.): From Prehistoric Villages to Cities. Settlement Aggregation and Community Transformation. New York - London, 44-62.

P. Fischl, K. - KiENLin, T. L. 2013: Results of a systematic survey programme on the Hatvan sites of Emőd-Nagyhalom and Tard-Tatárdomb in Northern Hungary. Acta Archaeologica Academiae Scientiarum Hungaricae 64, 5-32.

Garašanin, M. V. - GaRAšAnin, D. 1957: Praistorisko naselje crnoj bari. L'habitat prehistorique de Crna Bara. Rad Vojvodanskih Muzeja 6, 199-218.

Gauss, R. K. - Bátora, J. - Nowaczinski, E. - Rassmann, K. - Schukraft, G. 2012: The Early Bronze Age settlement of Fidvár, Vráble (Slovakia): reconstructing prehistoric settlement patterns using portable XRF. Journal of Archaeological Science 40, 2942-2960.

Goldman, Gy. - G. SzÉNÁszky, J. 2012: A Tiszapolgár kultúra települési egysége Battonya-Vertánmajor lelőhelyen. In: Kreiter, A. - Pető, Á. - Tugya, B. (eds): Környezet-Ember-Kultúra: Az alkalmazott természettudományok és a régészet párbeszéde. Budapest, 215-224.

52 HoRvÁth 1987, 42.

53 SCHIER 2008; 2013.

54 GARAŠANIN - GARAŠANIN 1957; LINK 2006, 124-125.

55 RACZKY - SiKLÓSI 2013; RACZKY ET AL. 2014. 
Hansen, S. - Toderaş, M. 2010: Pietrele und die neuen Dimensionen kupferzeitlicher Siedlungen an der Unteren Donau. In: Hansen, S. (ed.): Leben auf dem Tell als Soziale Praxis. Beiträge des internationalen Symposiums in Berlin vom 26. - 27. Februar 2007. Kolloquien zur Vor- und Frühgeschichte. Bonn, 85-106.

Hajdú, Zs. - NAGy, E. 2000: Újabb neolit leletek Hajdú-Bihar megyéből. Recent Neolithic Findings from Hajdú-Bihar County. In: Hajdú, Zs. - NAGy, E. (eds.): "Biharország” neolitikuma. Válogatás a környék újkőkori leleteiből. Neoliticul în judeţele Bihor şi Hajdú-Bihar. Neolithic of "Bihar-Area”. Debrecen - Oradea, 33-39.

Hertelendi, E. - Kalicz, N. - Raczky, P. - Horváth, F. - Veres, M. - Svingor, É. - Futó, I. - BarTosiewicz, L. 1995: Re-evaluation of the Neolithic in Eastern Hungary based on calibrated dates. Radiocarbon 37, 2, 239-245.

Horváth, F. 1987: Hódmezővásárhely-Gorzsa. A settlement of the Tisza culture. In: TÁLAs, L. Raczky, P. (eds): The Late Neolithic of the Tisza Region. A survey of recent excavations and their findings: Hódmezővásárhely-Gorzsa, Szegvár-Tüzköves, Öcsöd-Kováshalom, Vésztő-Mágor, Berettyóújfalu-Herpály. Budapest - Szolnok, 31-46.

HoRvÁth, F. 1989: A Tisza-vidék újkőkori településrendszerének és háztípusainak áttekintése. Übersicht über das Siedlungssystem und die Haustypen der Theissgegend im Neolithikum. A Móra Ferenc Múzeum Évkönyve 1988/1, 15-40.

Horváth, F. - Draşovean, F. 2013: Remarks on the Connections between the Banat and the Great Hungarian Plain at the beginning of the Middle Neolithic (Satchinez-Alföld Linear PotteryEsztár-Vinča). In: Anders, A. - Kulcsár, G. (eds.): Moments in Time. Papers presented to Pál Raczky on His $60^{\text {th }}$ Birthday. Ösrégészeti Tanulmányok / Prehistoric Studies 1. Budapest, 113-131.

Horváth, F. - Hertelendi, E. 1994: Contribution to the 14C based absolute chronology of the Early and Middle Neolithic Tisza region. Megjegyzések a Tisza-vidék korai és középső neolitikumának 14C alapú abszolút kronológiájához. A nyíregyházi fósa András Múzeum Évkönyve 36, 111-133.

Kalicz, N. 1995: Siedlungsstruktur der neolithischen Herpály-Kultur in Ostungarn. In: Aspes, A. (ed.): Settlement Patterns between the Alps and the Black Sea 5th to 2nd Millenium B.C. Verona Lazise 1992. Memorie del Museo Civico di Storia Naturale di Verona (IIa serie) Sezione Scienze dell'Uomo 4. Verona - Milano, 67-75.

Kalicz, N. - MakкAy, J. 1977: Die Linienbandkeramik in der Großen Ungarischen Tiefebene. Studia Archaeologica 7. Budapest.

Kalicz, N. - Raczky, P. 1984: Preliminary Report on the 1977-1982 excavations at the Neolithic and Bronze Age Tell Settlement at Berettyóújfalu-Herpály. I. Acta Archaeologica Academiae Scientiarum Hungaricae 36, 85-136.

Kalicz, N. - Raczky, P. 1987a: The Late Neolithic of the Tisza Region: A survey of recent archaeological research. In: TÁlas, L. - RAczky, P. (eds.): The Late Neolithic of the Tisza Region. A survey of recent excavations and their findings: Hódmezővásárhely-Gorzsa, Szegvár-Túzköves, Öcsöd-Kováshalom, Vésztó-Mágor, Berettyóúffalu-Herpály. Budapest - Szolnok, 11-30.

Kalicz, N. - Raczky, P. 1987b: Berettyóújfalu-Herpály. In: TÁlas, L. - Raczky, P. (eds.): The Late Neolithic of the Tisza Region. A survey of recent excavations and their findings: Hódmezővásárhely-Gorzsa, Szegvár-Túzköves, Öcsöd-Kováshalom, Vésztő-Mágor, BerettyóújfaluHerpály. Budapest-Szolnok, 105-125.

Kalicz, N. - Anders, A. - Raczky, P. 2011: Preserved by Ancestral fires. Pictures of an excavation the Neolithic village at Berettyóúffalu-Herpály. Budapest. 
KoRek, J. 1987: Szegvár-Tüzköves. A settlement of the Tisza culture. In: TÁLAs, L. - RAczky, P. (eds): The Late Neolithic of the Tisza Region. A survey of recent excavations and their findings: Hódmezővásárhely-Gorzsa, Szegvár-Tüzköves, Öcsöd-Kováshalom, Vésztö-Mágor, Berettyóúffalu-Herpály. Budapest-Szolnok, 47-60.

LINK, T. 2006: Das Ende der neolithischen Tellsiedlungen. Universitätsforschungen zur prähistorischen Archäologie 134. Bonn.

Mаккау, J. 1957: A bihari Berettyóvölgy őskori leletei. Prähistorische Funde im Berettyótale. A Déri Múzeum Évkönyve 1948-1956, 21-42.

Sz. MÁтнÉ, M. 1978: Újkőkori település Berettyószentmárton-Morotva lelőhelyen. Neusteinzeitliche Siedlung im Fundgebiet Berettyószentmárton-Morotva. A debreceni Déri Múzeum évkönyve, $35-56$.

Sz. MÁthÉ, M. 1980: Berettyóújfalu-Szilhalom. Régészeti Füzetek I, 33, 7-8.

Sz. MÁthé, M. 1981: Berettyóújfalu környékének története az őskorban. In: VARGA, Gy. (ed.): Berettyóújfalu története. Berettyóújfalu, 11-39.

Sz. Máthé, M. 1988: Bronze Age tells in the Berettyó valley. In: Kovács, T. - Stanczik, I. (eds.): Bronze Age Tell Settlements of the Great Hungarian Plain I. Inventaria Praehistorica Hungariae 1. Budapest, 27-122.

Parkinson, W. A. 2006: The social organization of Early Copper Age tribes on the Great Hungarian Plain. British Archaeological Reports International Series 1573. Oxford.

Parkinson, W. A. - Gyucha, A. 2007: A késő neolitikum-kora rézkor átmeneti időszakának társadalomszerkezeti változásai az Alföldön. Rekonstrukciós kísérlet. Die Veränderungen in der Gesellschaftsstruktur der Übergangsperiode vom Spätneolithikum zur frühen Kupferzeit in der Grossen Ungarischen Tiefebene. Rekonstruktionsversuch. Archaeologiai Értesitő 132, 37-81.

Parkinson, W. A. - Yerkes, R. W. - Gyucha, A. - Sarris, A. - Morris, M. - Salisbury, R. B. 2010 : Early Copper Age Settlements in the Körös Region of the Great Hungarian Plain. Journal of Field Archaeology 35, 164-183.

Patay, P. 1974: Die hochkupferzeitliche Bodrogkeresztúr-Kultur. Berichte der Römisch-Germanischen Kommission 55, 1-71.

Peters, S. - Borisov, A. V. - Reinhold, S. - Korobov, D. S. - Thiemeyer, H. 2014: Microbial characteristics of soils depending on the human impact on archaeological sites in the Northern Caucasus. Quaternary International 324, 162-171.

RACzKy, P. 1995: Neolithic settlement patterns in the Tisza region of Hungary. In: Aspes, A. (ed.): Settlement Patterns between the Alps and the Black Sea 5th to 2nd Millenium B.C. Verona - Lazise 1992. Memorie del Museo Civico di Storia Naturale di Verona (IIa serie) Sezione Scienze dell'Uomo 4. Verona - Milano, 77-86.

Raczky, P. - Anders, A. 2008: Late Neolithic spatial diferentiation at Polgár-Csőszhalom, eastern Hungary. In: Bailey, D. W. - Whittle, A. - Hofmann, D. (eds.): Living Well Together? Settlement and Materiality in the Neolithic of South-East and Central Europe. Oxford, 35-53.

RAczky, P. - ANDERs, A. 2009: Régészeti kutatások egy késő neolitikus településen - Polgár-Bosnyákdomb (Előzetes jelentés). Archaeological research at a Late Neolithic settlement - PolgárBosnyákdomb (Preliminary report). Archaeológiai Értesitő 134, 5-21.

Raczky, P. - Anders, A. 2010: Activity loci and data for spatial division at a late Neolithic sitecomplex (Polgár-Csőszhalom: a case study). In: Hansen, S. (eds.): Leben auf dem Tell als Soziale Praxis. Beiträge des internationalen Symposiums in Berlin vom 26. - 27. Februar 2007. Kolloquien zur Vor- und Frühgeschichte 2010. Bonn 143-164. 
Raczky, P. - Anders, A. - Bartosiewicz, L. 2011: The Enclosure System of Polgár-Csőszhalom and its Interpretation. In: HANSEN, S. - MÜLLER, J. (eds.): Sozialarchäologische Perspektiven: Gesellschaftlicher Wandel 5000-1500 v. Chr. zwischen Atlantik und Kaukasus. Archäologie in Eurasien 24, 57-79.

RACZky, P. - ANDERs, A. - SEBőK, K. - Csippán, P. in press: Chronologies of human activities on the Polgár-Csőszhalom site. Berlin.

Raczky, P. - ANDERs, A. - Siklósi Zs. 2014: Trajectories of Continuity and Change between the Late Neolithic and the Copper Age in Eastern Hungary. In: Schier, W. - Draşovean, F. (eds.): The Neolithic and Eneolithic in Southeast Europe. New approaches to dating and cultural dynamics in the 6th to 4th Millenium BC. Prähistorische Archäologie in Südosteuropa 28. Rahden/Westf., 319-346.

Raczky, P. - Fodor, I. - Mester, Zs. 2010: Régészeti kutatások Hajdúböszörmény-Pródi-halmon Archaeological research at Hajdúböszörmény-Pródi-halom, Hungary. Archaeologiai Értesitő 135, 161-182.

Raczky, P. - Siklósi, Zs. 2013: Reconsideration of the Copper Age chronology of the eastern Carpathian Basin: a Bayesian approach. Antiquity 87, 555-573.

Reimer, P. J. - Bard, E. - Bayliss, A. - Beck, J. W. - Blackwell P. G. - Bronk Ramsey, C. - Buck, C. E. - Cheng, H. - Edwards, R. L. - Friedrich, M. - Grootes, P. M. - Guilderson, T. P. Haflidason, H. - Hajdas, I. - Hatté, C. - Heaton, T. J. - Hoffmann, D. L. - Hogg, A. G. Hughen, K. A. - Kaiser, K. F. - Kromer, B. - Manning, S. W. - Niu, M. - Reimer, R. W. Richards, D. A. - Scott, E. M. - Southon, J. R. - Staff, R. A. - Turney, C. S. M. -van der Plicht, J. 2013: IntCal13 and Marine13 radiocarbon age calibration curves 0-50,000 years cal BP. Radiocarbon 55/4, 1869-1887.

SchIER, W. 2008: Uivar: a late Neolithic-early Eneolithic fortified tell site in western Romania. In: Bailey, D. W. - Whittle, A. - Hofmann, D. (eds.): Living Well Together? Settlement and Materiality in the Neolithic of South-East and Central Europe. Oxford, 54-67.

SchIER, W. 2013: An Antiquarian's Grave? Early Tiszapolgár Burials in the Late Vinča Tell Site of Uivar (Romania). In: Anders, A. - Kulcsár, G. (eds.): Moments in Time. Papers Presented to Pál Raczky on His 60th Birthday. Ösrégészeti Tanulmányok / Prehistoric Studies 1. Budapest, 569-577.

Sherratt, A. 1983: The development of neolithic and copper age settlement in the Great Hungarian Plain. Part II: Site Survey and settlement dynamics. Oxford Journal of Archaeology 2/1, 13-41.

SüMegi, P. - Molnár, S. 2007: The Kiri-tó Meander: Sediments and the Question of Floods. In: Whittle, A. (ed.): The Early Neolithic on the Great Hungarian Plain. Investigations of the Körös culture site of Ecsegfalva 23, County Békés. Varia Archaeologica Hungarica 21. Budapest, 67-98.

Yerkes, R. W. - Gyucha, A. - Parkinson, W. A. 2009: A Multi-Scalar Approach to Modeling the End of the Neolithic on the Great Hungarian Plain Using Calibrated Radiocarbon Dates. Radiocarbon 51, 1071-1109. 


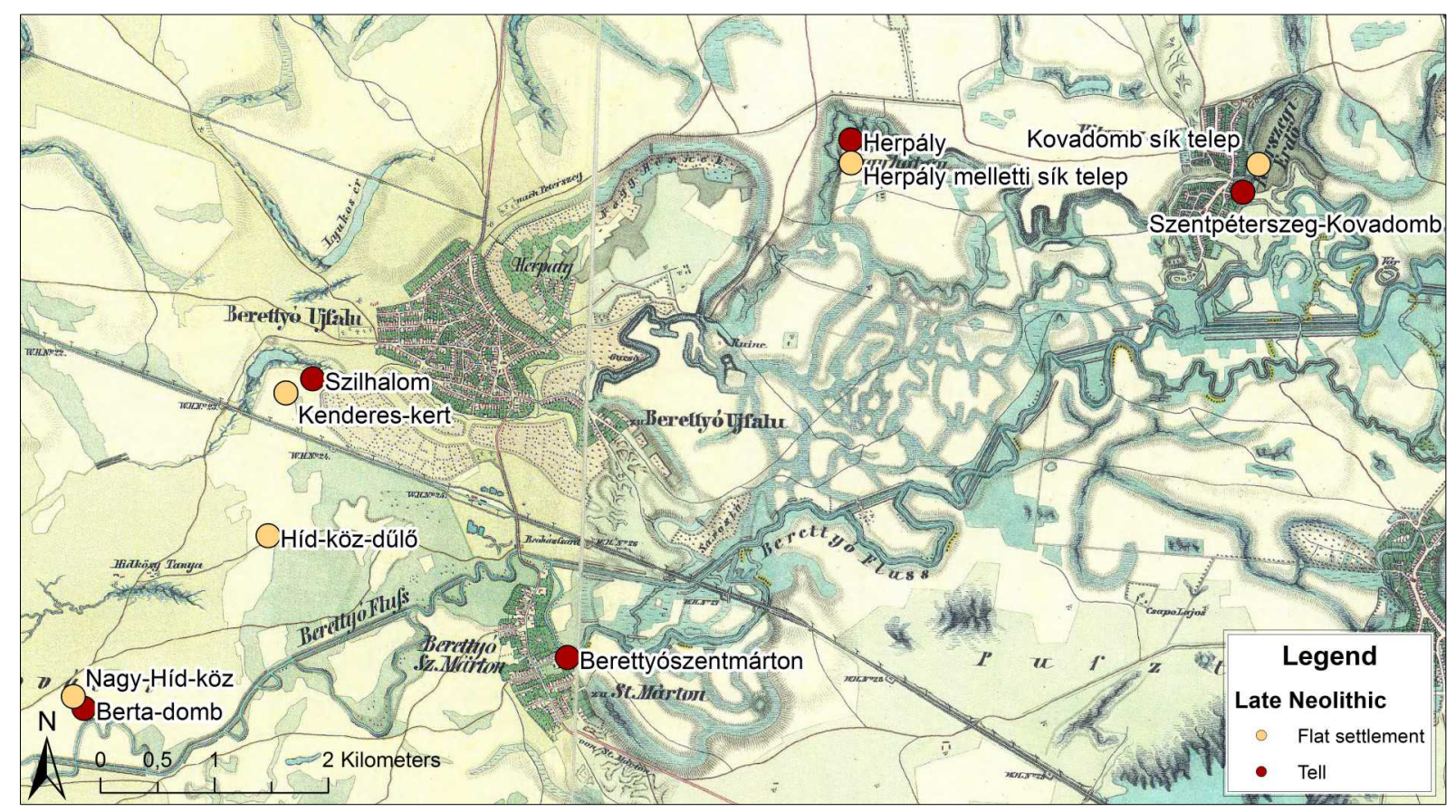

Fig. 1. Late Neolithic sites in the vicinity of Berettyóújfalu (Zs. Siklósi).

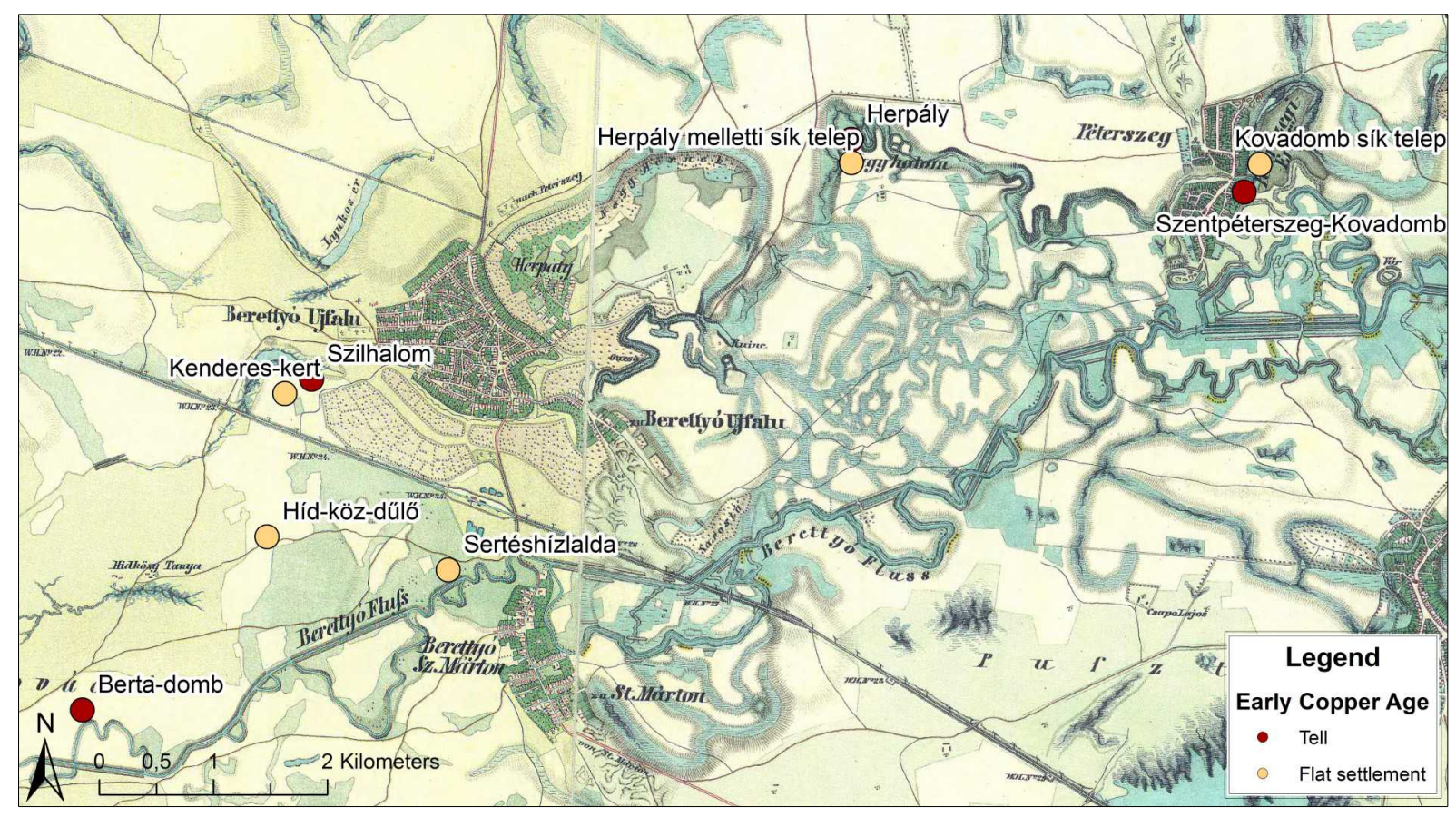

Fig. 2. Early Copper Age sites in the vicinity of Berettyóújfalu (Zs. Siklósi). 


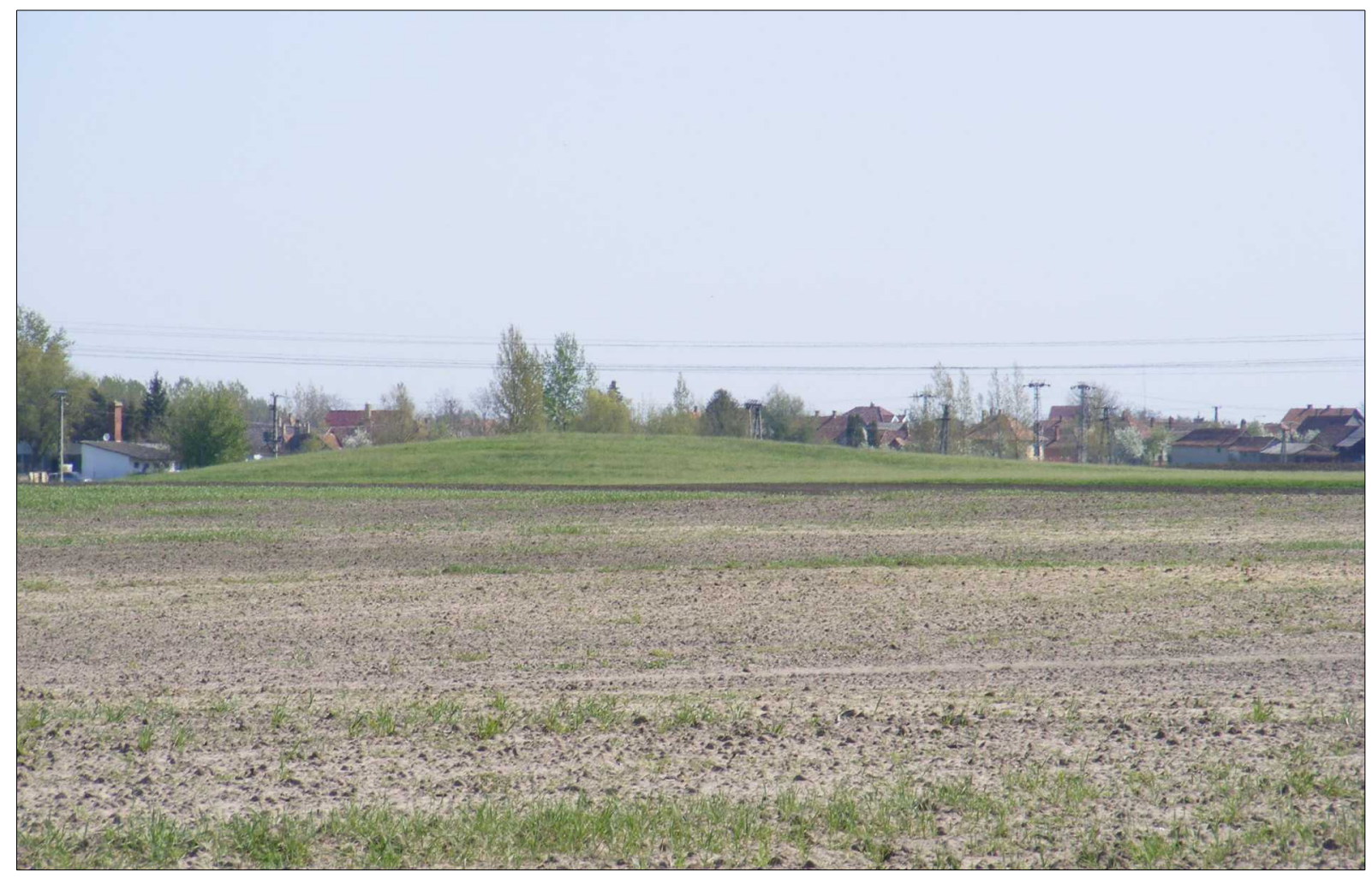

Fig. 3. View on Berettyóújfalu-Szilhalom from the West (Photo: Zs. Siklósi).

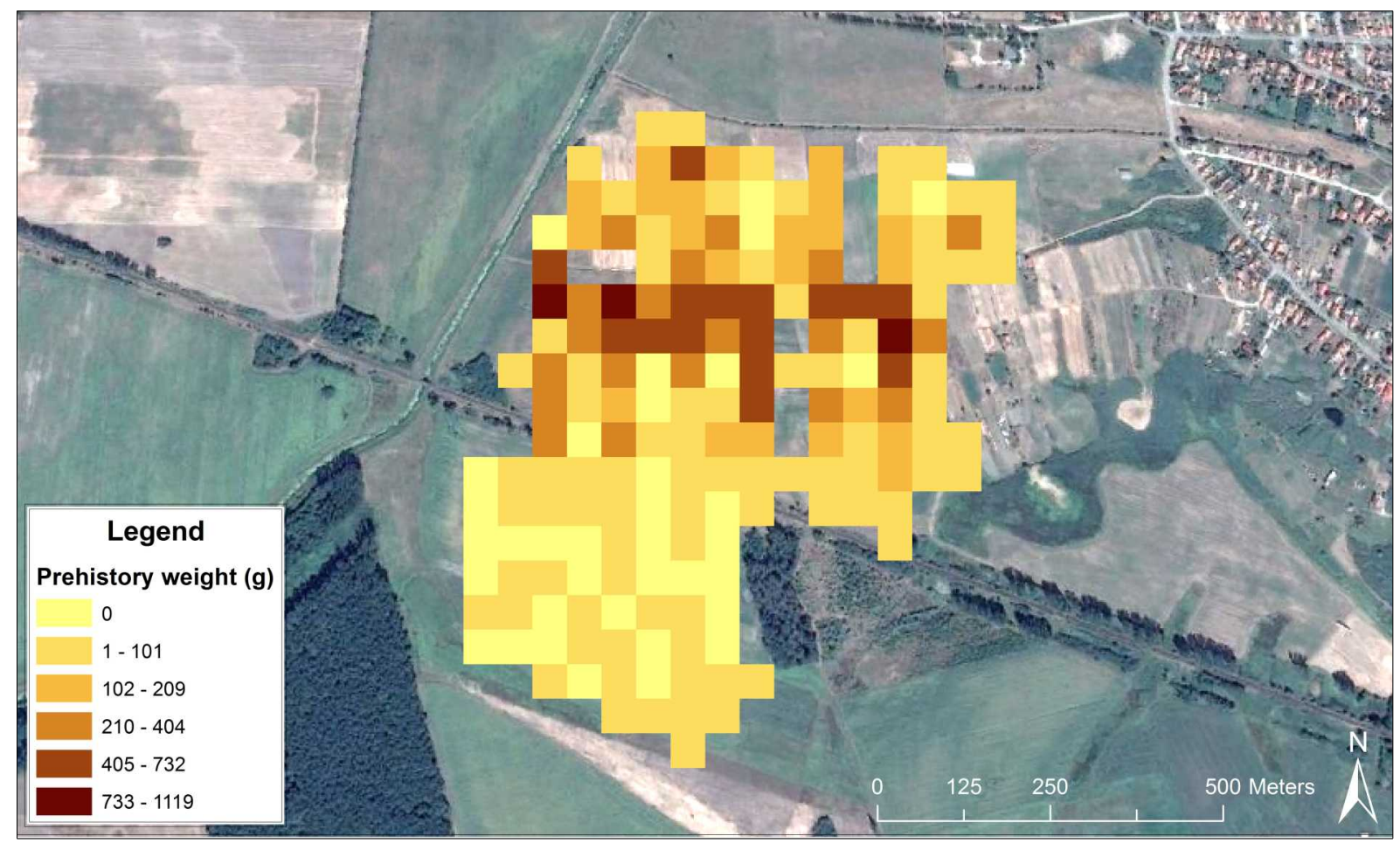

Fig. 4. Weight of prehistoric sherds collected by fieldwalking in 2013 (Zs. Siklósi). 


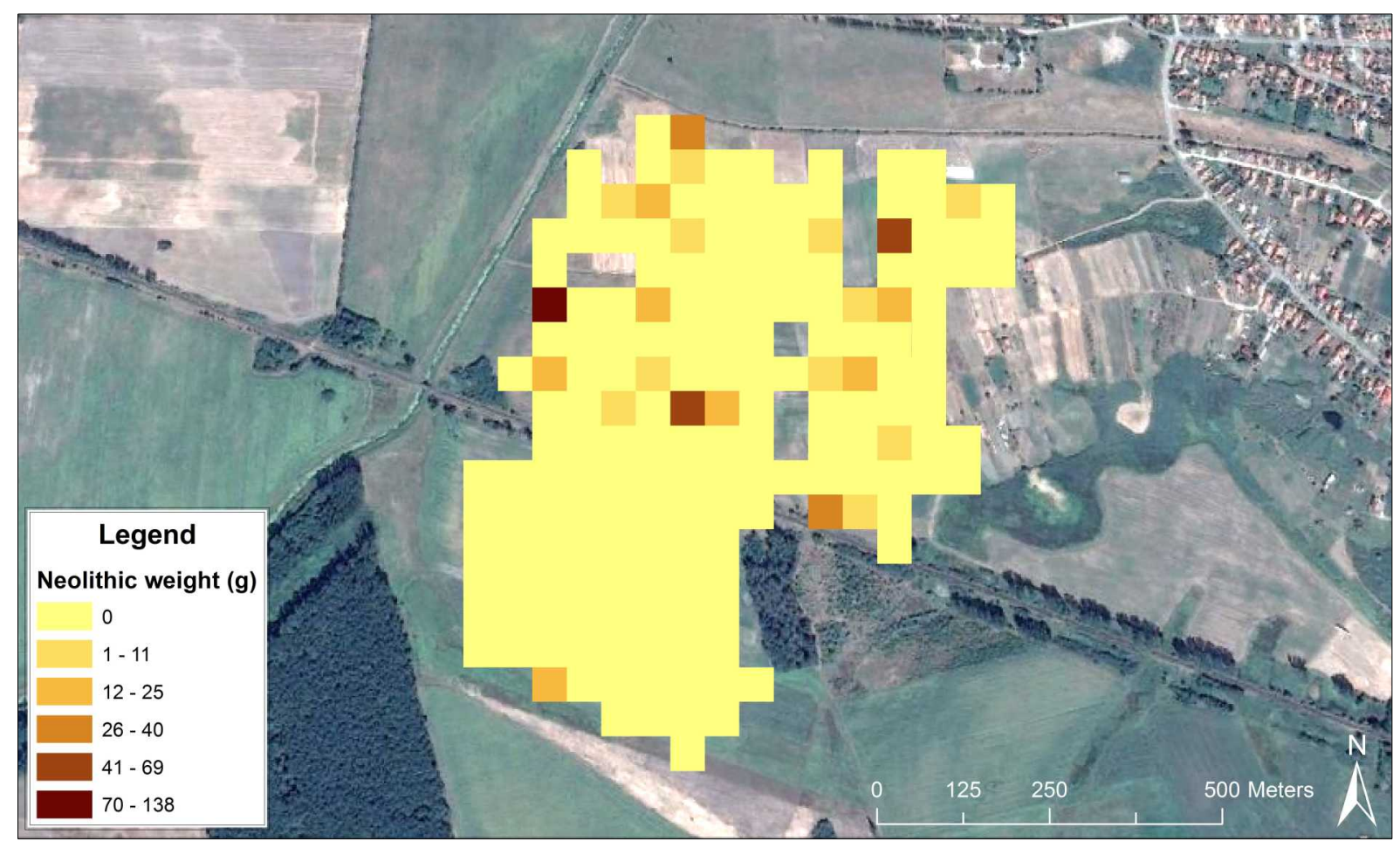

Fig. 5. Weight of Neolithic sherds collected by fieldwalking in 2013 (Zs. Siklósi).

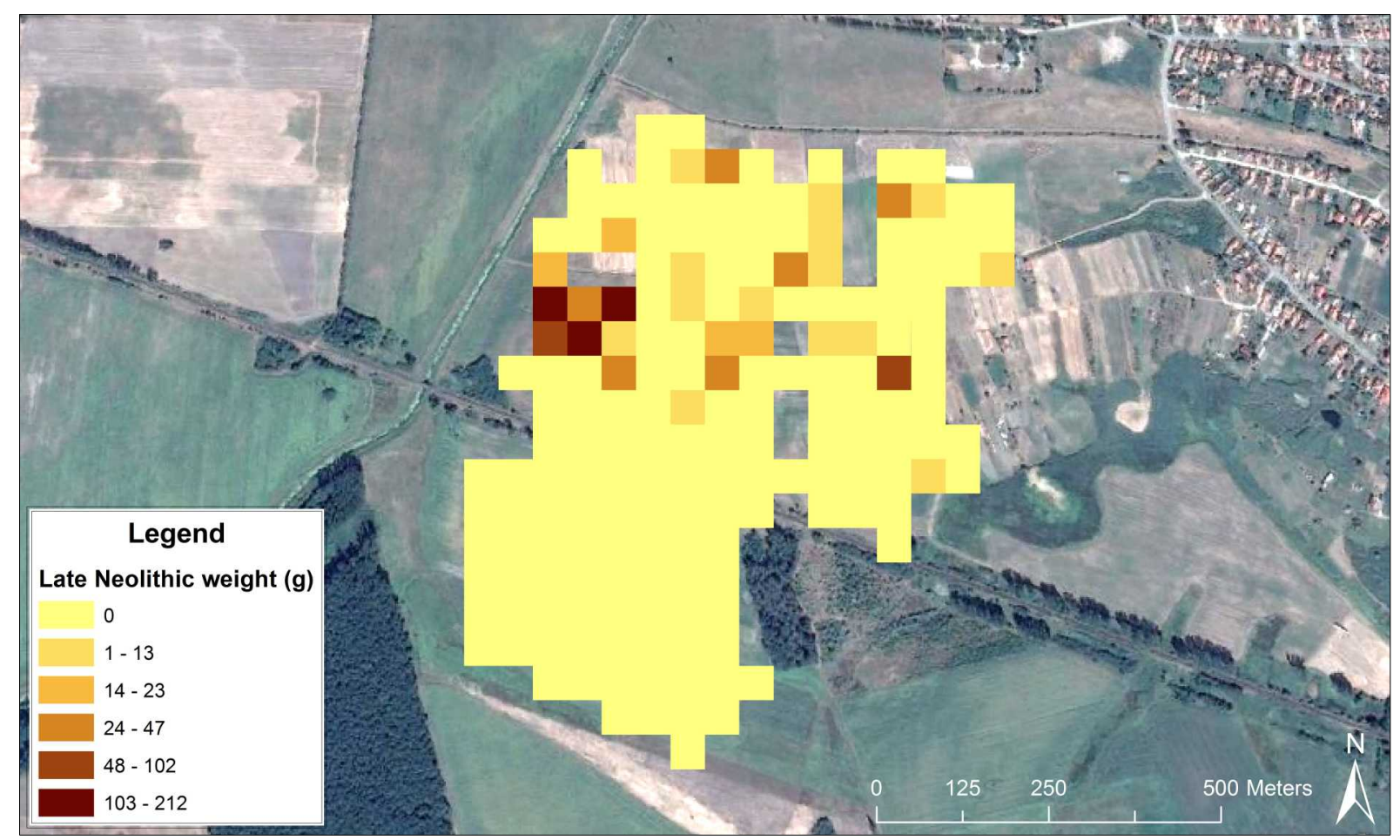

Fig. 6. Weight of Late Neolithic sherds collected by fieldwalking in 2013 (Zs. Siklósi). 


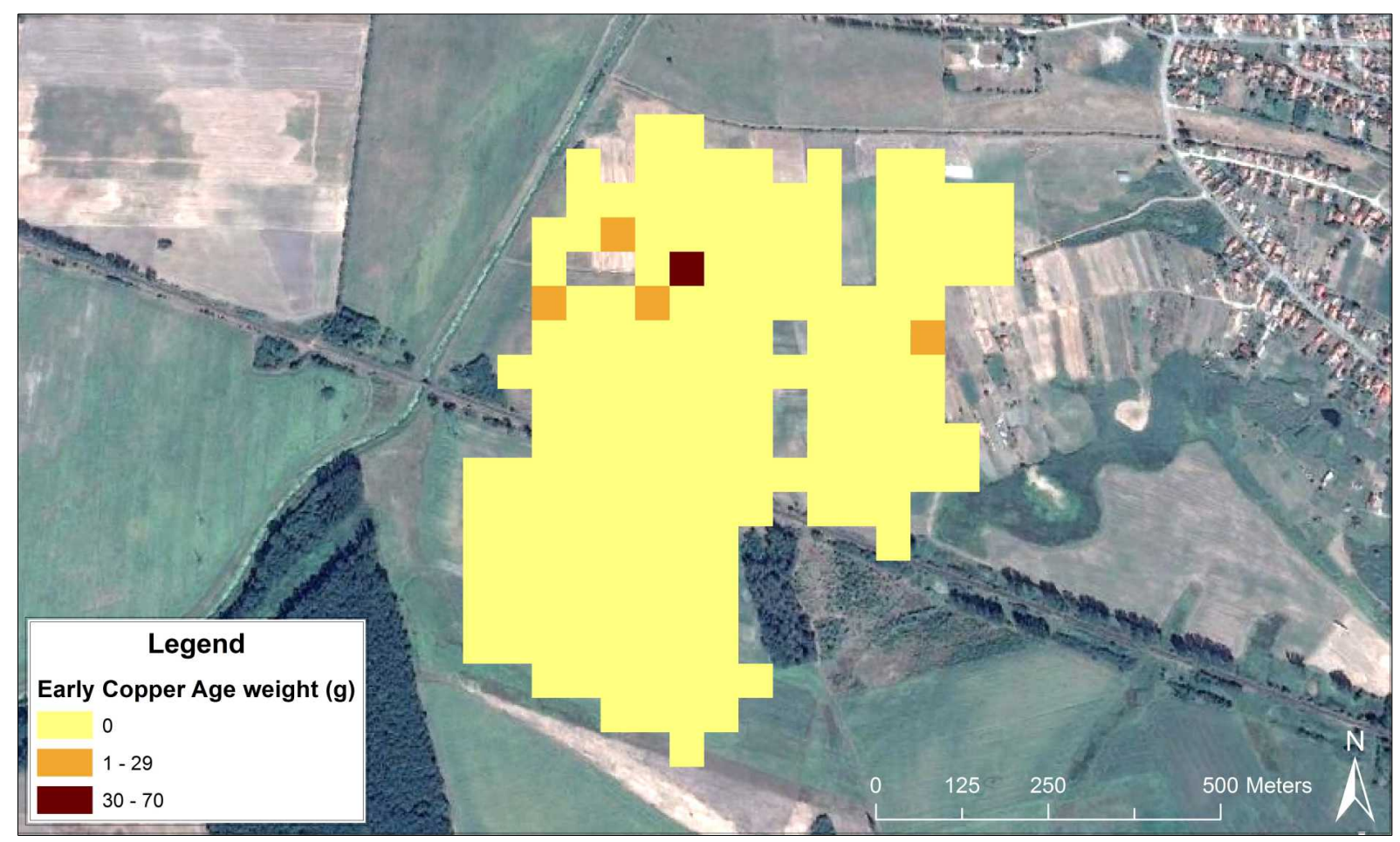

Fig. 7. Weight of Early Copper Age sherds collected by fieldwalking in 2013 (Zs. Siklósi).

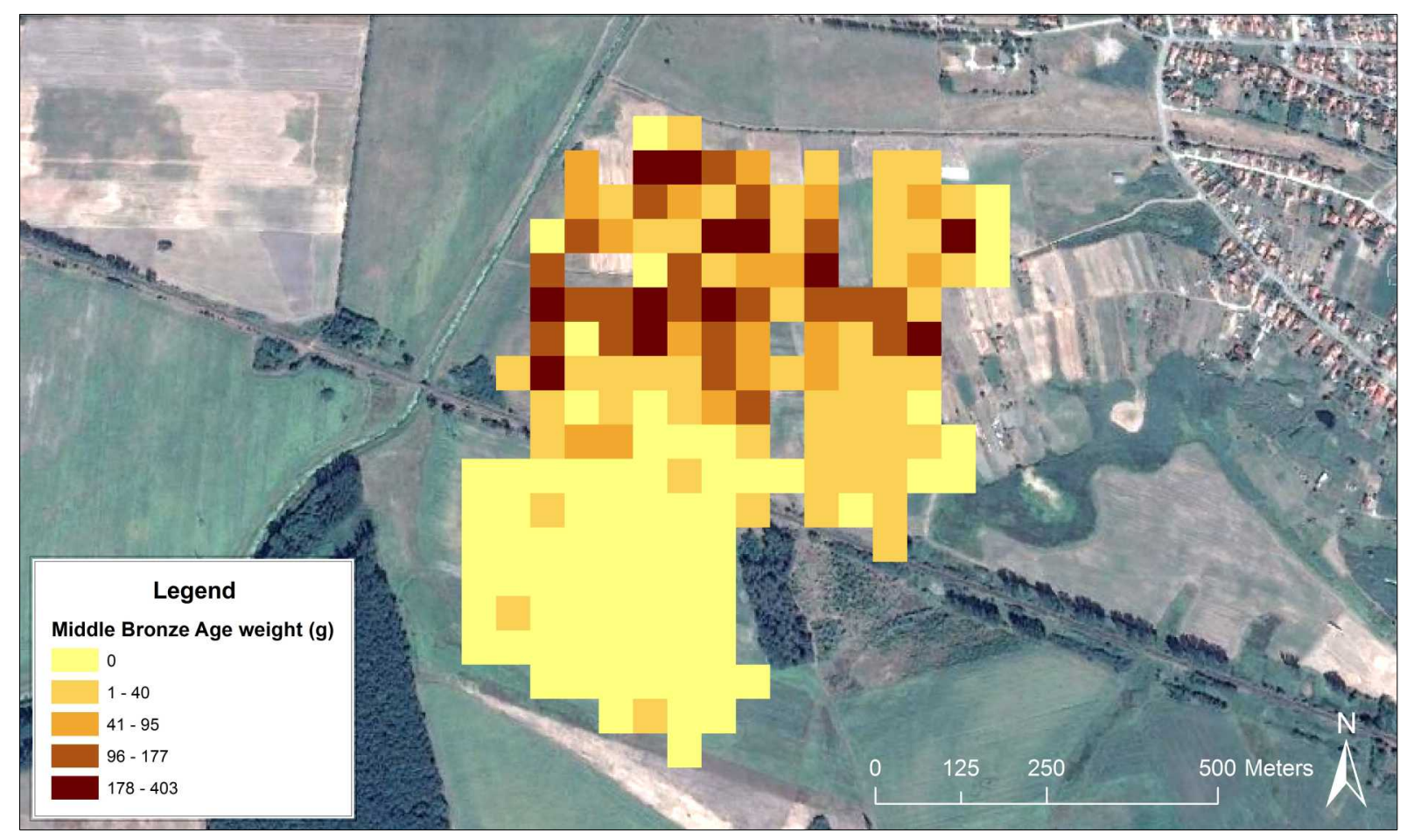

Fig. 8. Weight of Middle Bronze Age sherds collected by fieldwalking in 2013 (Zs. Siklósi). 


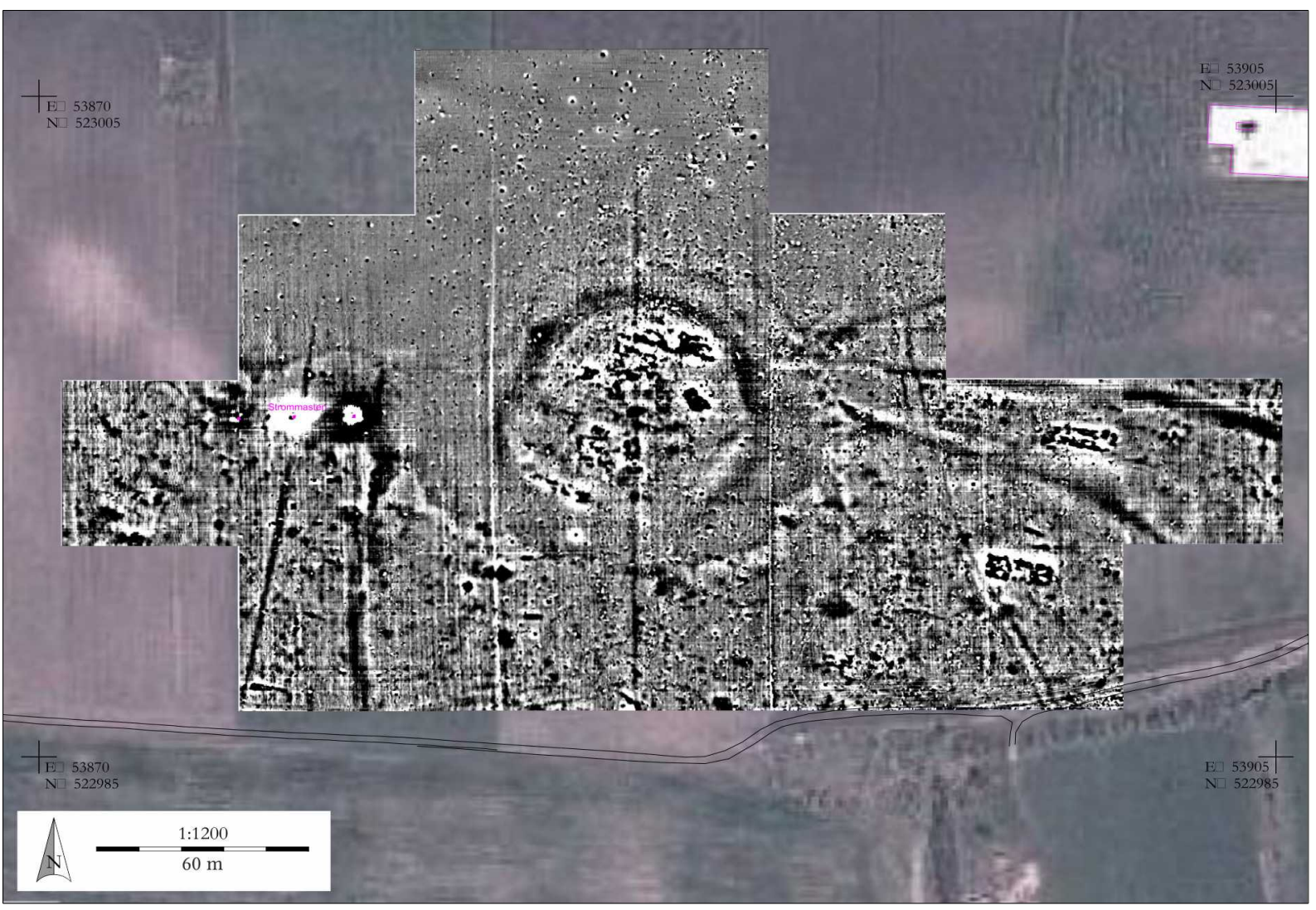

Fig. 9. Magnetogram of Berettyóújfalu-Szilhalom (R. Scholz).

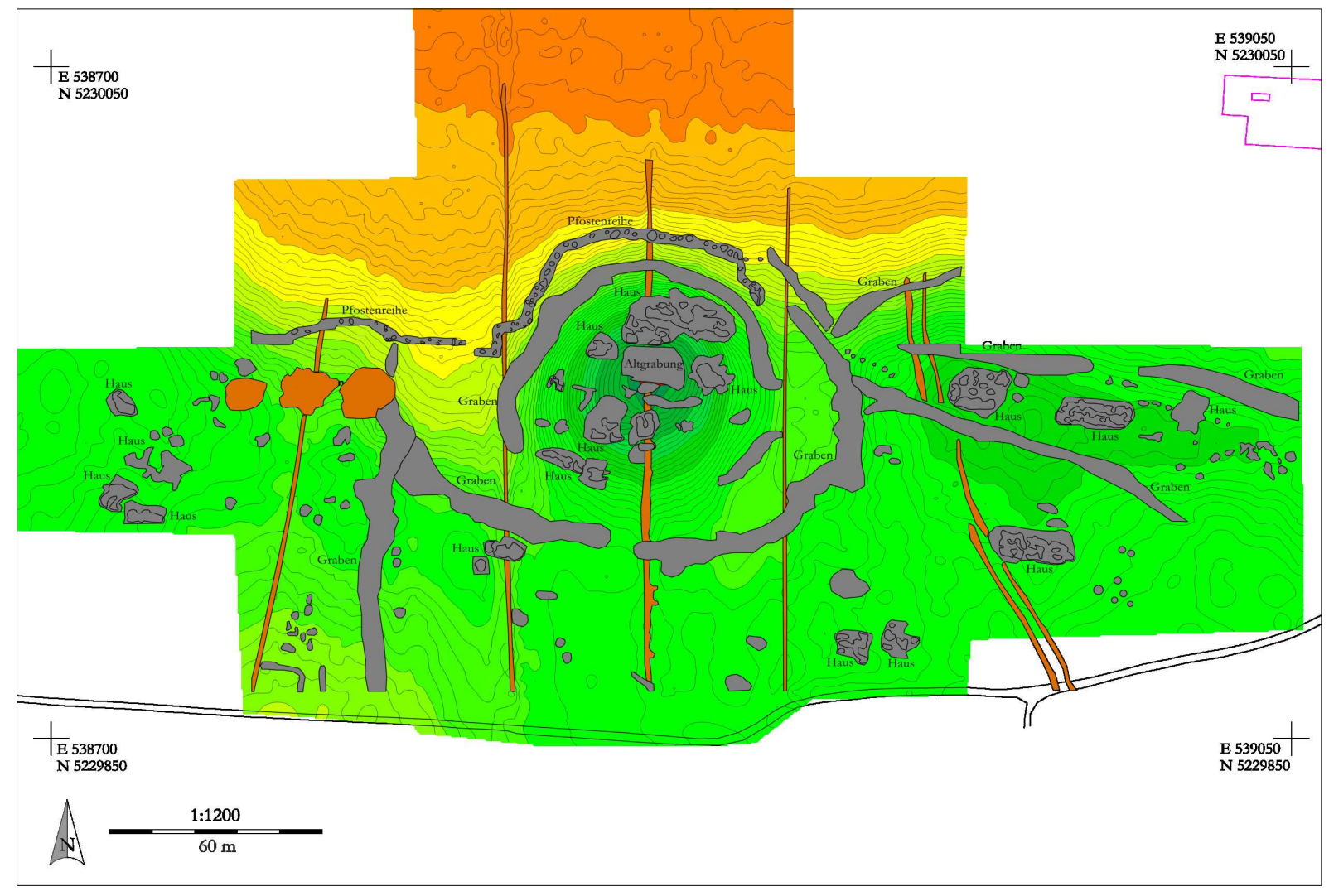

Fig. 10. Interpretation of magnetogram of Berettyóújfalu-Szilhalom (R. Scholz). 
D. Neumann - Zs. Siklósi - R. Scholz - M. Szilágyi: Preliminary report on the first season of fieldwork...

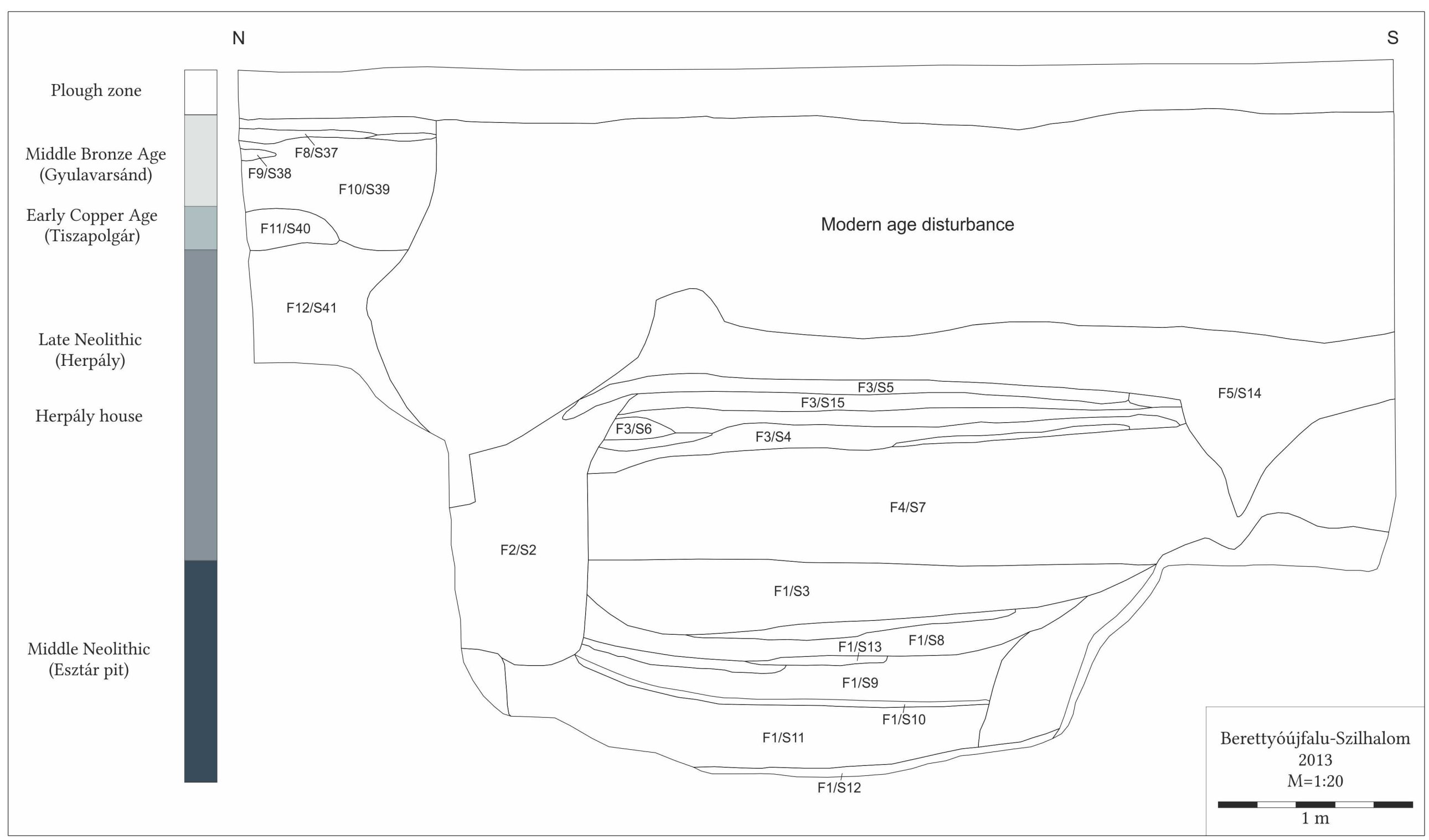

Fig. 11. The eastern profile of the multi-layered settlement (M. Szilágyi - R. Scholz - D. Neumann). 


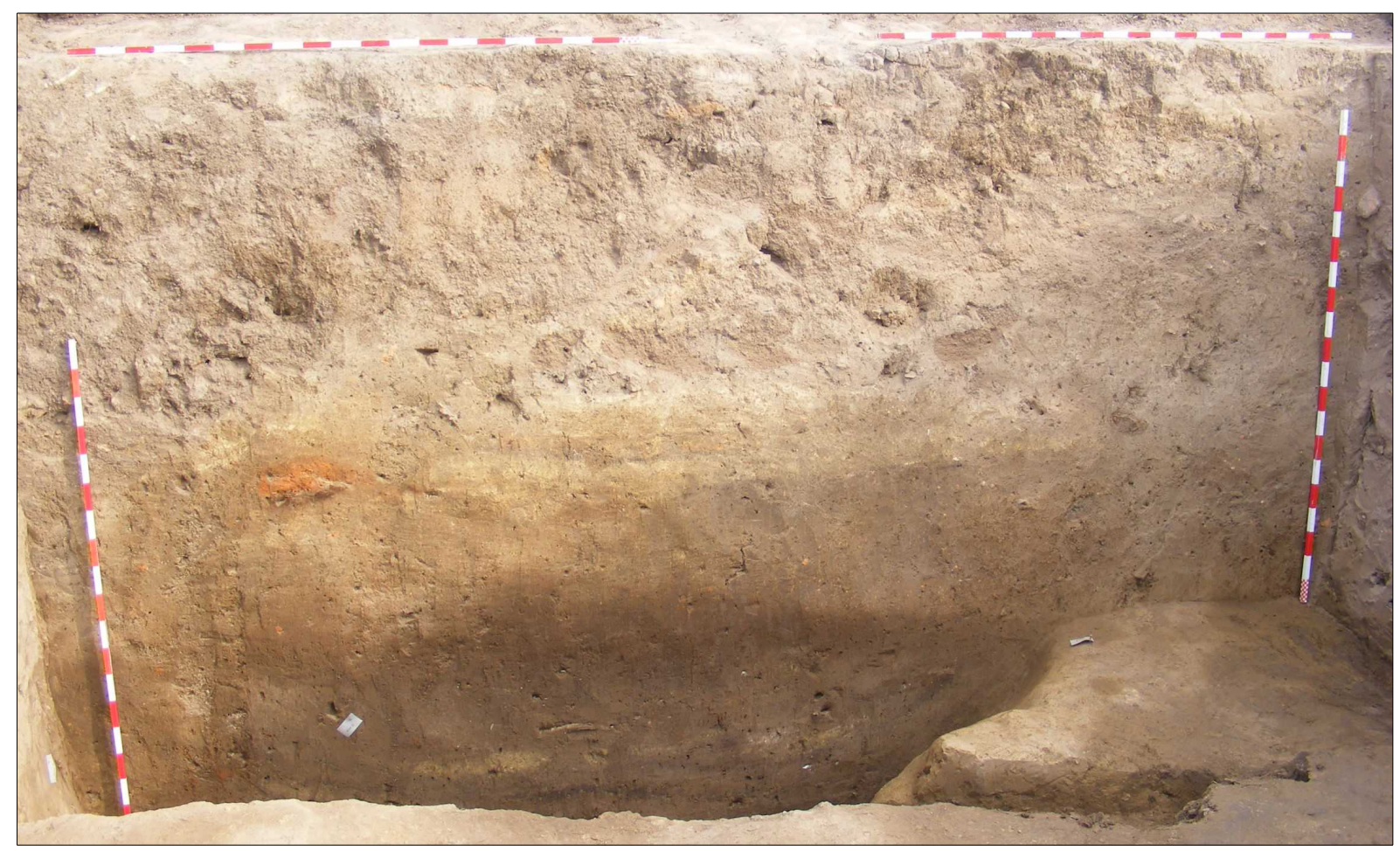

Fig. 12. Photo of the eastern profile (Zs. Siklósi).

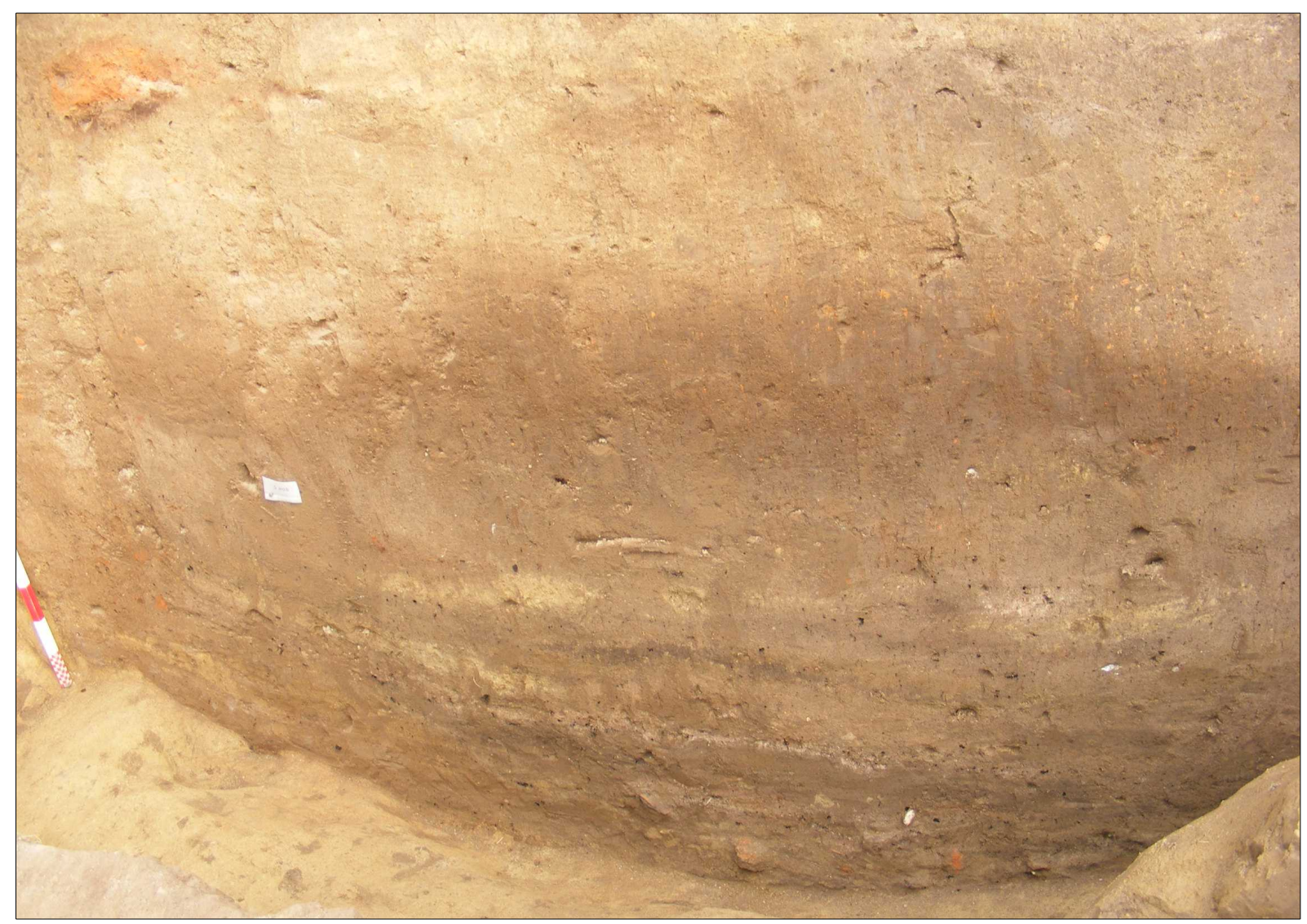

Fig. 13. Photo of the Middle Neolithic Esztár pit (Zs. Siklósi). 


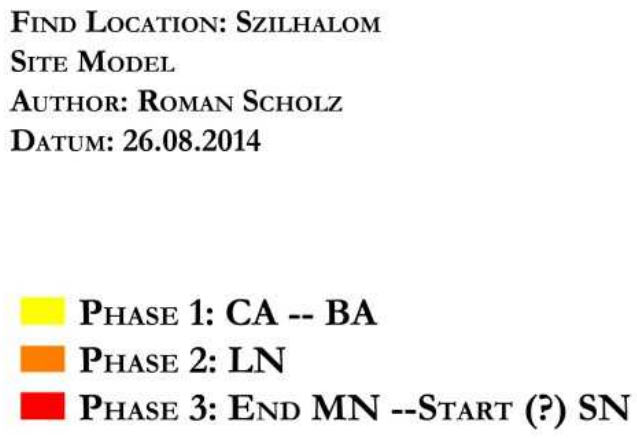

Find Location: Szilhalom

SITE Model

Author: Roman SchOLZ

DATUM: 26.08.2014

Phase 1: CA -- BA

Phase 2: LN

Phase 3: END MN --START (?) SN

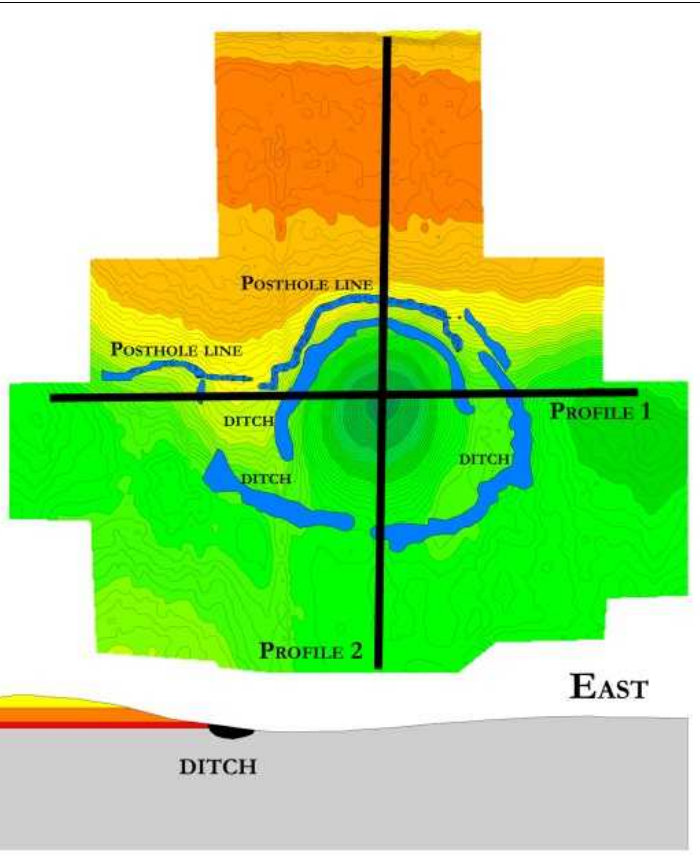

South

Fig. 14. Intersections of the tell and hypothetical settlement and ditch stratigraphy (R. Scholz).

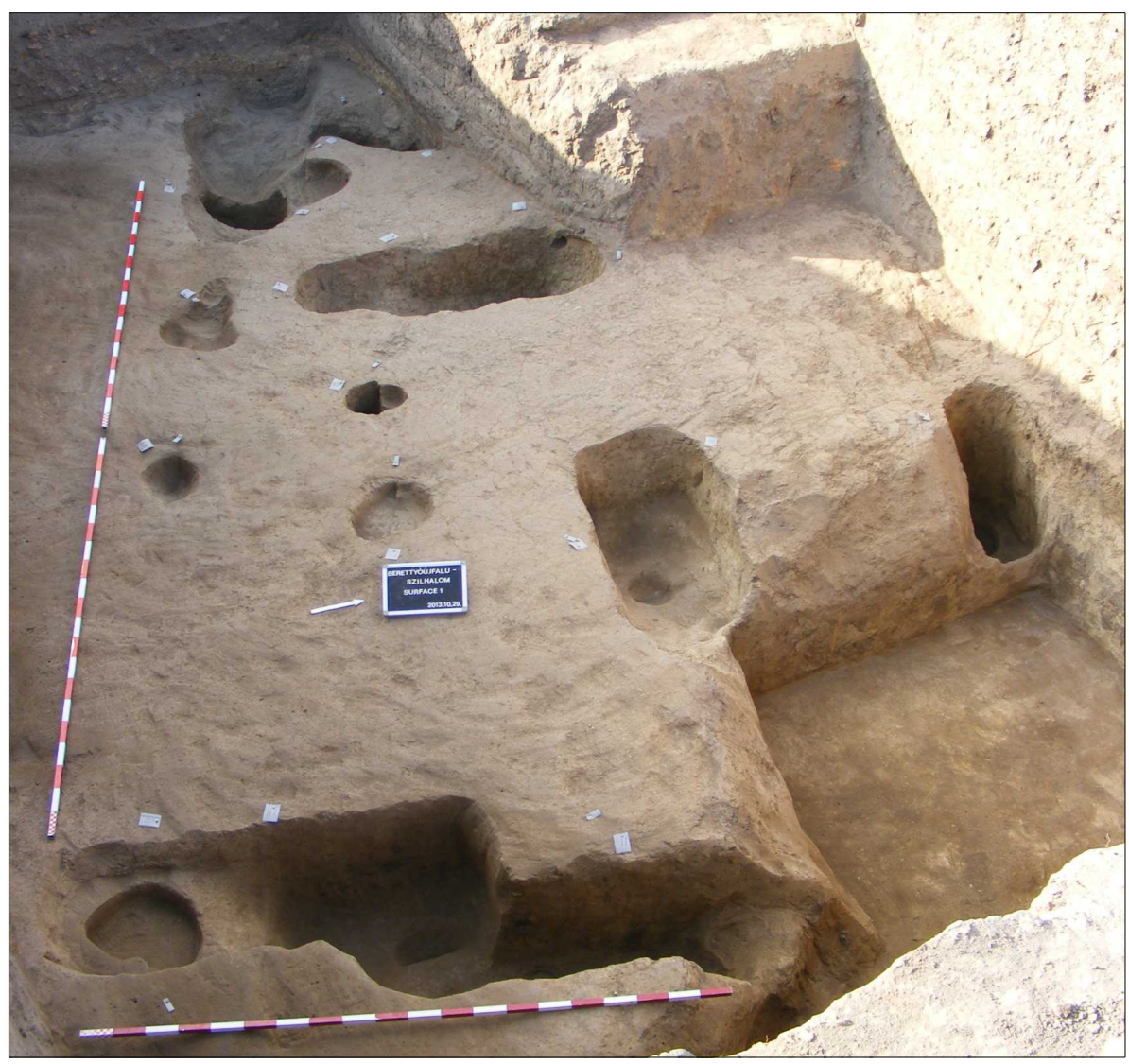

Fig. 15. Photo of Late Neolithic timber-framed houses (Zs. Siklósi). 


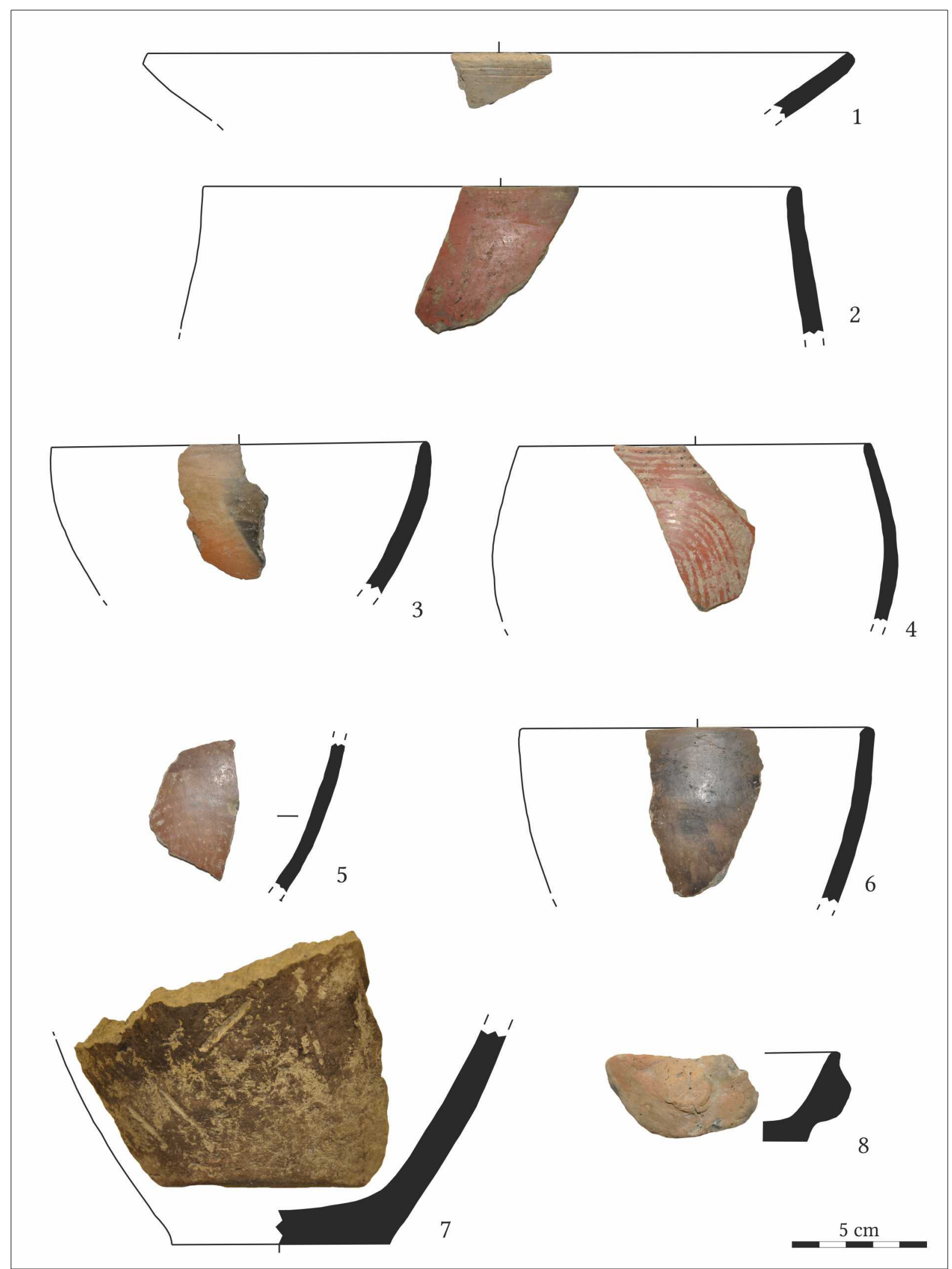

Fig. 16. Esztár sherds from the Middle Neolithic pit (M. Szilágyi). 

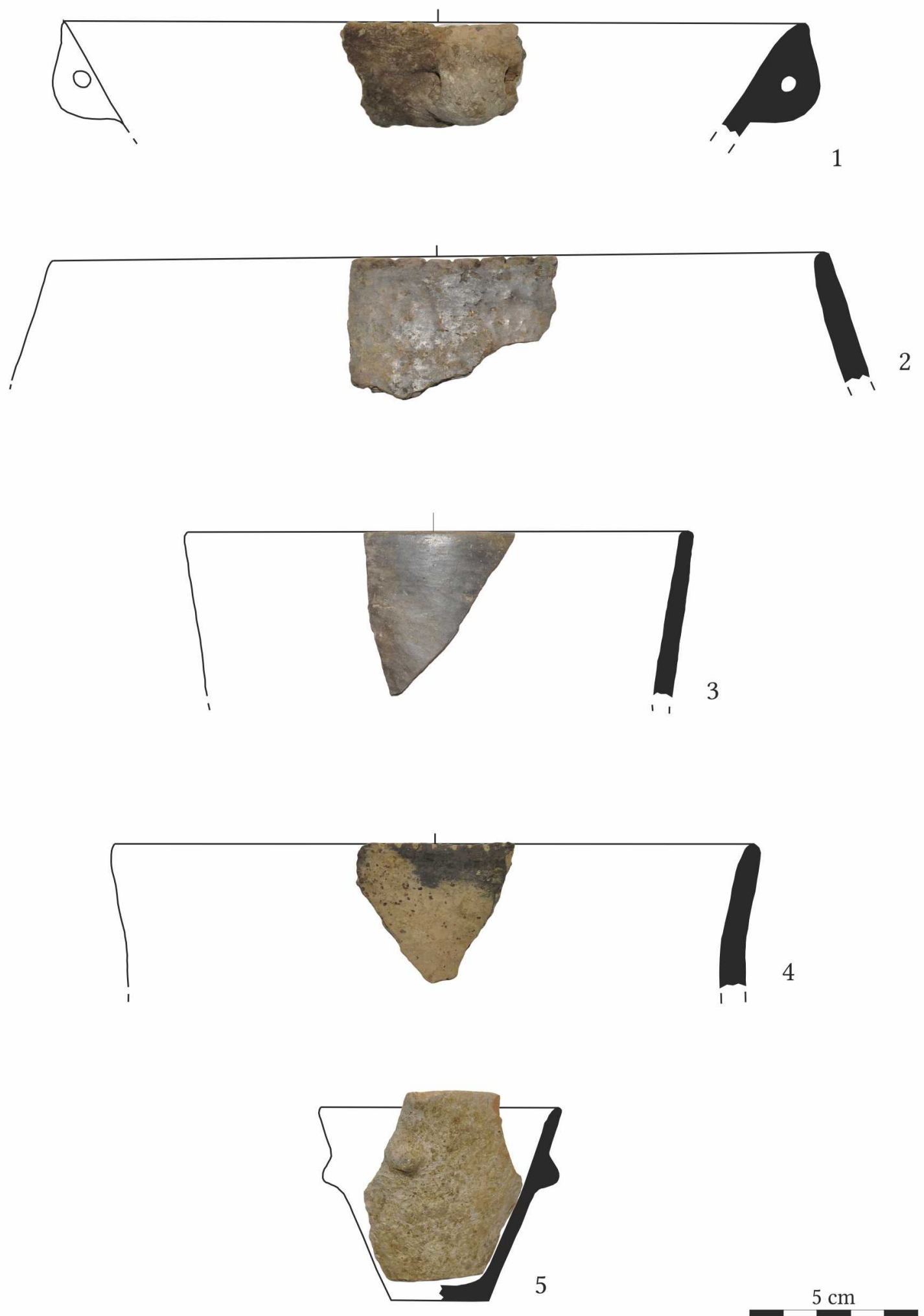

4

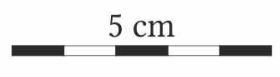

Fig. 17. Herpály sherds from the Late Neolithic layers (M. Szilágyi). 

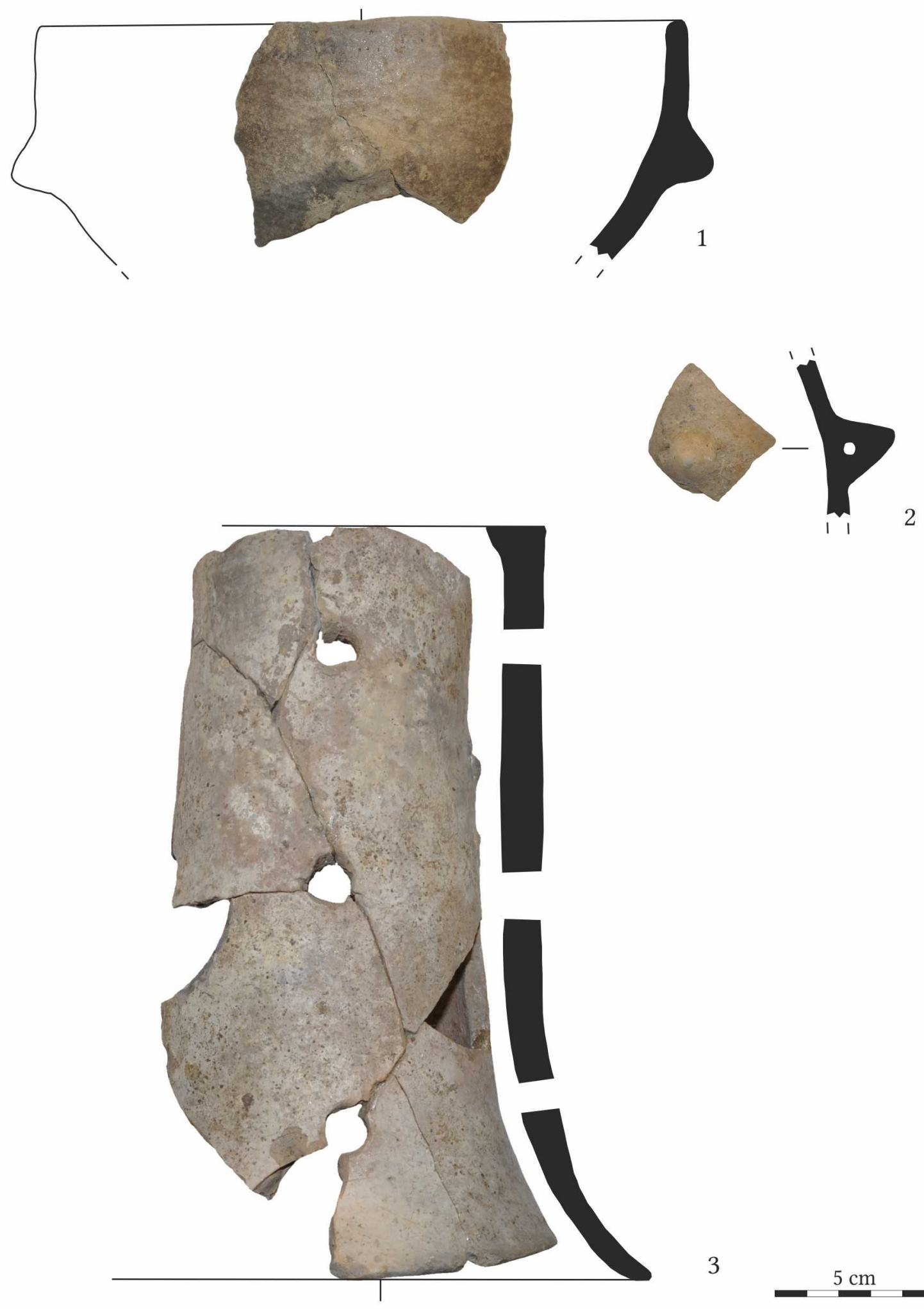

3

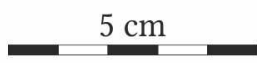

Fig. 18. Tiszapolgár sherds from the debris of an Early Copper Age house (M. Szilágyi). 
D. Neumann - Zs. Siklósi - R. Scholz - M. Szilágyi: Preliminary report on the first season of fieldwork...

\begin{tabular}{|c|c|c|c|c|c|c|c|}
\hline Lab. No. & $\begin{array}{c}\text { Feature/ } \\
\text { Stratigraphic } \\
\text { unit }\end{array}$ & $\begin{array}{c}\text { Material of the } \\
\text { sample }\end{array}$ & $\begin{array}{l}\text { C14 } \\
\text { (BP) }\end{array}$ & $\begin{array}{l}\text { Standard } \\
\text { deviation }\end{array}$ & $13 \mathrm{C}$ & $\begin{array}{l}\text { cal BC } \\
(68.2 \%)\end{array}$ & $\begin{array}{c}\text { cal BC } \\
(95.5 . \%)\end{array}$ \\
\hline MAMS-20 492 & F001/S008 & animal bone & 6197 & 19 & -15.7 & $5215-5075$ & $5225-5060$ \\
\hline MAMS-20 493 & F001/S009 & animal bone & 6210 & 19 & -12.7 & $5220-5075$ & $5290-5060$ \\
\hline MAMS-20 494 & F001/S012 & animal bone & 6252 & 20 & -17.8 & $5295-5215$ & $5305-5210$ \\
\hline MAMS-20 495 & F001/S013 & animal bone & 6216 & 20 & -18.8 & $5225-5075$ & $5290-5065$ \\
\hline MAMS-20496 & F002/S002 & animal bone & 6128 & 29 & -20.0 & $5205-4995$ & $5210-4990$ \\
\hline MAMS-20 497 & F003/S004 & animal bone & 5697 & 20 & -23.3 & $4550-4495$ & $4585-4460$ \\
\hline MAMS-20 498 & F003/S004 & animal bone & 5787 & 19 & -16.5 & $4690-4615$ & $4710-4555$ \\
\hline MAMS-20 499 & F004/S007 & animal bone & 5764 & 28 & -18.9 & $4680-4555$ & $4705-4540$ \\
\hline MAMS-20 500 & F004/S007 & animal bone & 5851 & 20 & -17.3 & $4770-4690$ & $4790-4685$ \\
\hline MAMS-20 501 & F005/S014 & animal bone & 5678 & 19 & -18.4 & $4540-4485$ & $4545-4460$ \\
\hline MAMS-20 502 & F005/S014 & animal bone & 5731 & 19 & -22.6 & $4605-4535$ & $4680-4500$ \\
\hline MAMS-20 503 & F002/S002 & animal bone & 6225 & 28 & -19.2 & $5295-5075$ & $5300-5065$ \\
\hline MAMS-20 504 & F011/S040 & animal bone & 5740 & 19 & -12.2 & $4610-4540$ & $4685-4525$ \\
\hline MAMS-20 505 & F011/S040 & animal bone & 5614 & 20 & -21.8 & $4465-4370$ & $4495-4365$ \\
\hline
\end{tabular}

Fig. 19. AMS radiocarbon dates for the layers of Berettyóújfalu-Szilhalom settlement. 
D. Neumann - Zs. Siklósi - R. Scholz - M. Szilágyi: Preliminary report on the first season of fieldwork...

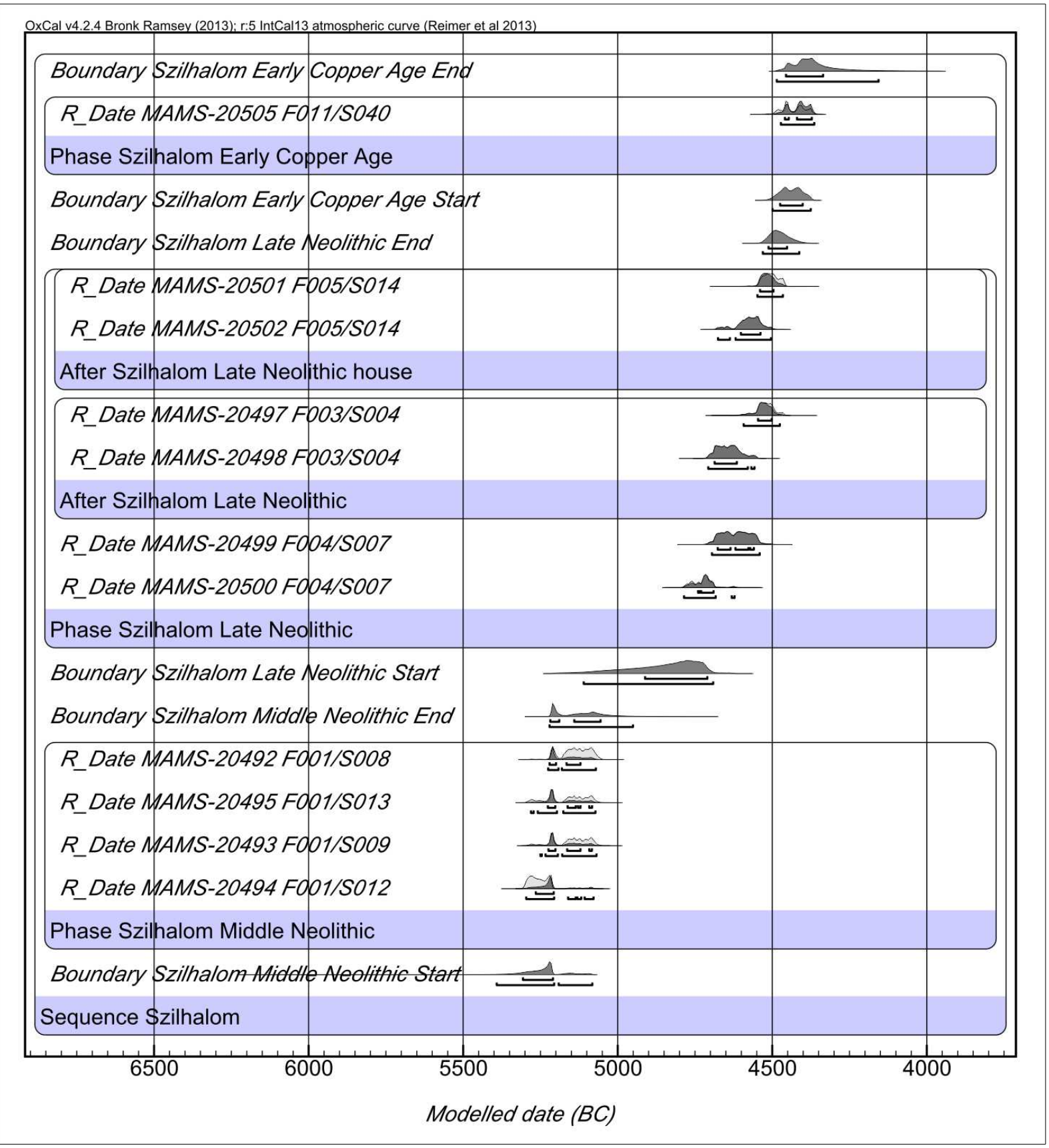

Fig. 20. Probability distributions of dates from Middle Neolithic, Late Neolithic and Early Copper Age layers of Berettyóújfalu-Szilhalom. 


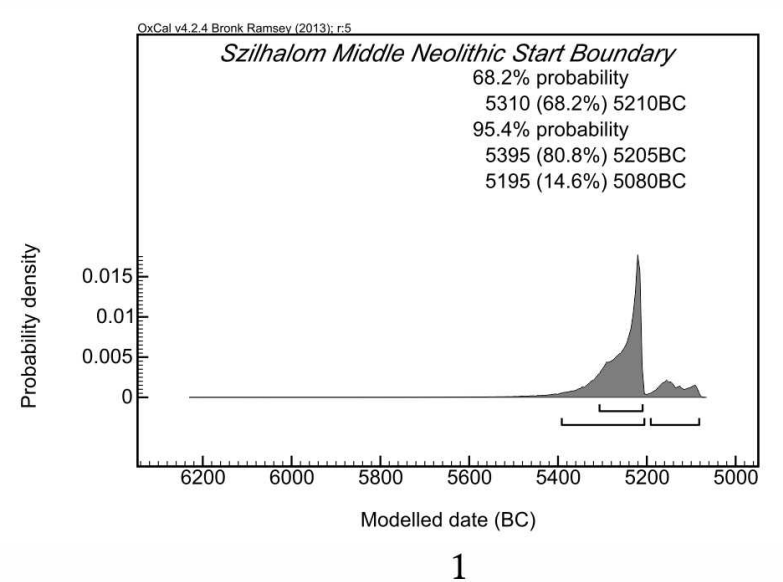

1

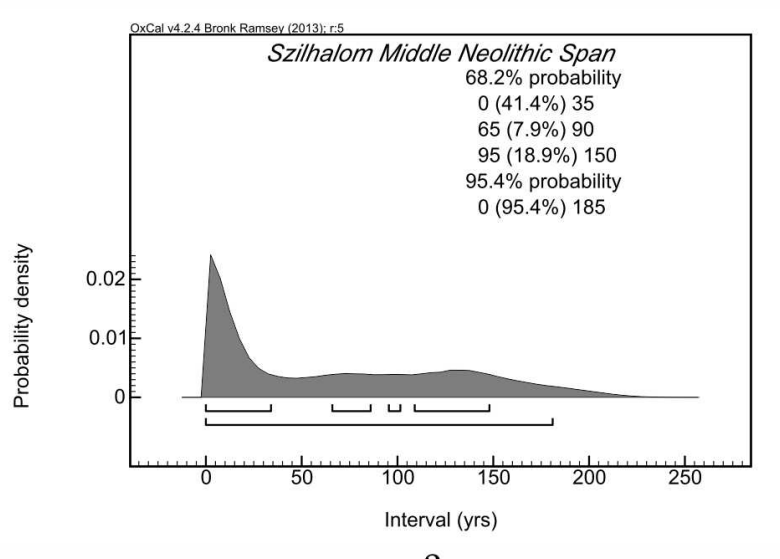

2

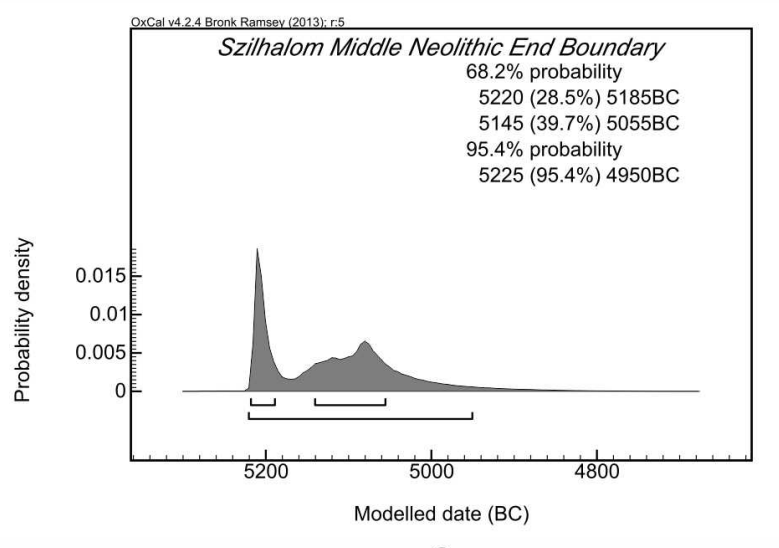

3

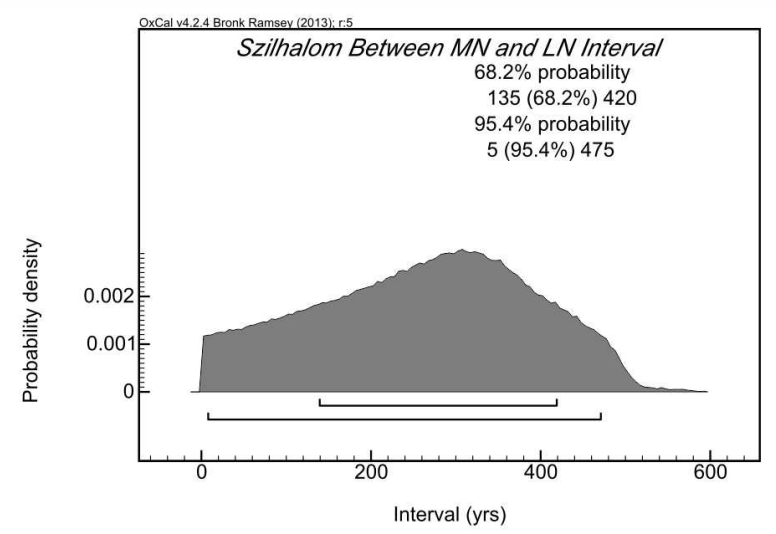

4

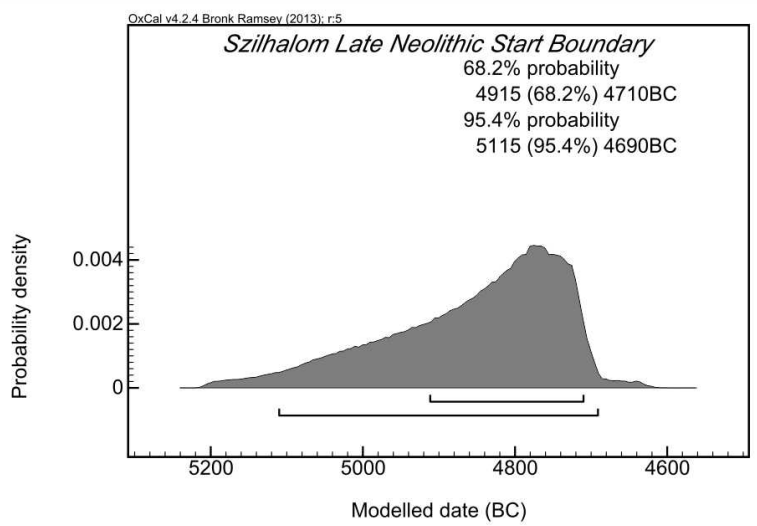

5

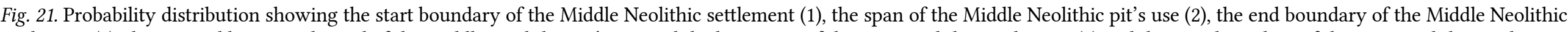

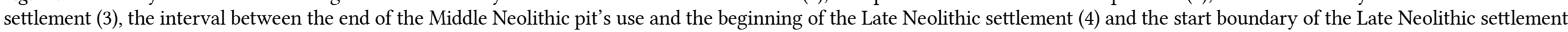
(5) in Berettyóújfalu-Szilhalom. 


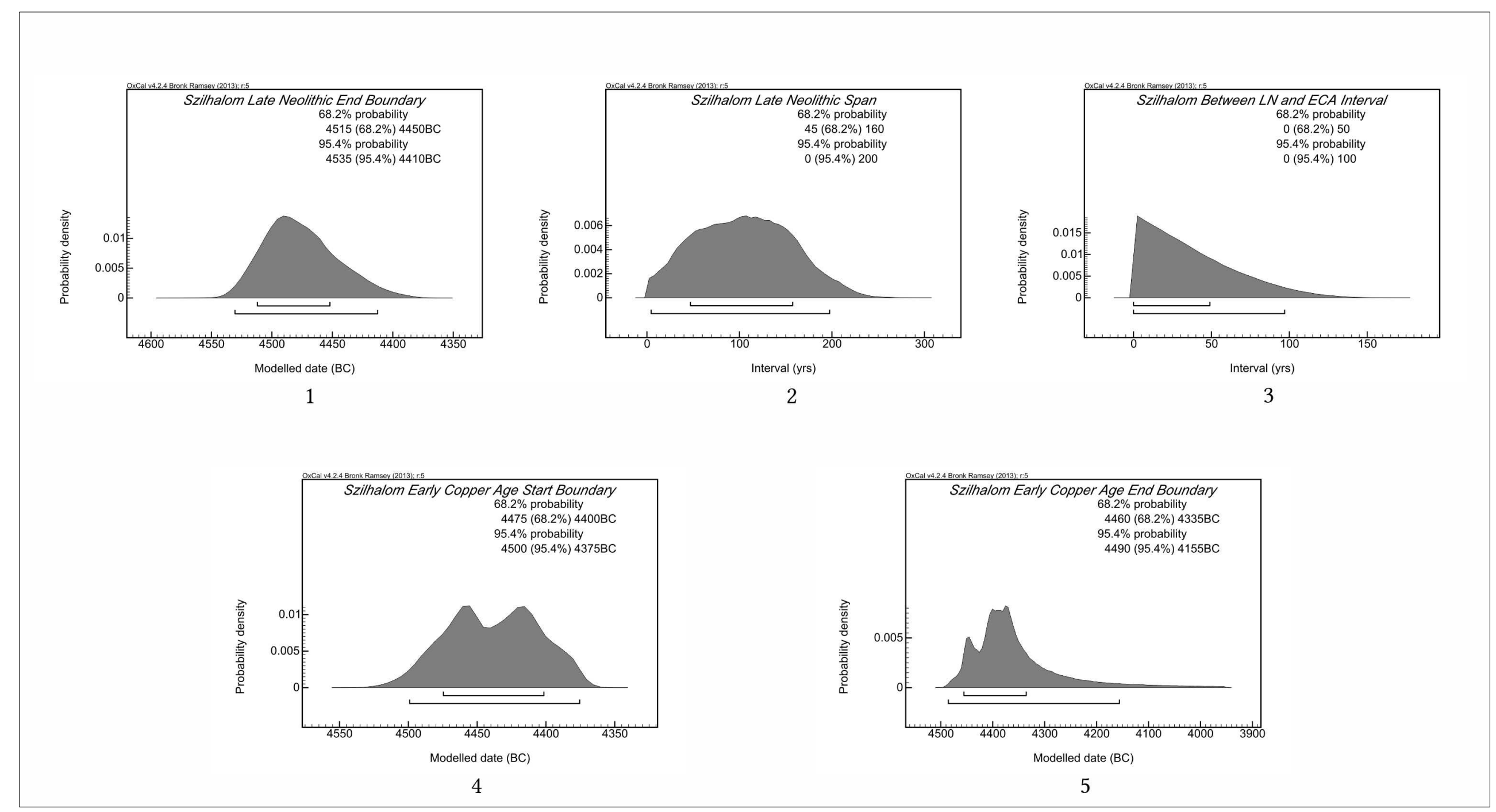

Fig. 22. Probability distribution showing the end boundary of the Late Neolithic settlement (1), the span of the Late Neolithic settlement's use (2), the interval between the end of the Late Neolithic settlement's use and the beginning of the Early Copper Age settlement (3), the start boundary of the Early Copper Age settlement (4) and the end boundary of the Early Copper Age settlement (5) in Berettyóújfalu-Szilhalom. 